\title{
13. MAESTRICHTIAN FORAMINIFERS FROM SITE 605, DEEP SEA DRILLING PROJECT LEG 93, NORTHWEST ATLANTIC1
}

\author{
H. Jansen, CIGARS B. V., Amsterdam \\ and \\ D. Kroon, Instituut voor Aardwetenschappen, Vrije Universiteit, Amsterdam²
}

\begin{abstract}
Upper Cretaceous clayey limestones of Cores 66 to 71 from Site 605 in the northwest Atlantic contain a highly diversified and well-preserved fauna of planktonic foraminifers.

The local Racemiguembelina fructicosa, Globotruncana contusa, and Globotruncana stuarti biozones correlate with standard Biozones UC17, UC16, and UC15, indicating a late Maestrichtian age for all the cores.

The co-occurrence of warm-water Tethyan taxa and "cool" boreal taxa points to a transitional biogeoprovince in the northwest Atlantic during late Maestrichtian times.
\end{abstract}

\section{INTRODUCTION}

This chapter documents the Maestrichtian foraminifers recovered from Cores 66 to 71, DSDP Site 605, located at $38^{\circ} 44.52^{\prime} \mathrm{N}, 72^{\circ} 36.55^{\prime} \mathrm{W}$, on the upper continental rise at a water depth of $2194 \mathrm{~m}, 180 \mathrm{~km}$ ESE of New Jersey (Fig. 1). A total of 42 samples were taken from a 55-m sequence of Maestrichtian clayey limestone rich in foraminifers and nannofossils, with minor occurrences of quartz grains and pyrite (Fig. 2). Core photographs show no indication of tectonic disturbance or mass transport. There are gradual changes in the color of the sediment and the cores are strongly bioturbated.

\section{METHODS}

All samples were dried, dissolved in a mixture of water and sodium carbonate, and washed over a $65-\mu \mathrm{m}$ sieve. Some samples required an "explosion" treatment before they could be washed; that is the sediment was saturated with gasoline and disaggregated in boiling water. We used a sample splitter on the $>125-\mu \mathrm{m}$ residue to obtain a random collection of 100-200 planktonic foraminifers. Larger portions of the residues were used to extract all benthic foraminifers $>125 \mu \mathrm{m}$ and to determine the percentage of benthic foraminifers in the total foraminiferal fauna (P/B ratio, Fig. 2). Benthic foraminifers were identified only to the generic level.

The preservation of the foraminifers is usually good, but never excellent. Larger specimens are often damaged. Palaeontologic materia has been deposited at the Institute for Earth Sciences, Free University, Amsterdam.

\section{RESULTS}

Taxonomy of the planktonic foraminifers largely follows the work of van Hinte (1963), Martin (1972), and Robaszynski et al. (1984). Benthic genera are identified from Loeblich and Tappan (1964). The faunas are dominated by planktonic foraminifers with minor amounts

\footnotetext{
${ }^{1}$ van Hinte, J. E., Wise, S. W., Jr., et al., Init, Repts. DSDP, 93: Washington (U.S Govt, Printing Office).

2 Addresses: (Jansen) CIGARS B. V., P.O. Box 18123, 1001 ZA, Amsterdam, The Netherlands; (Kroon) VU-Instituut voor Aardwetenschappen, P.O. Box 7161, 1007 MC, Amsterdam, The Netherlands.
}

of benthic foraminifers, and rare ostracode and echinoid fragments. The planktonic fauna indicates a late Maestrichtian age for our samples (Fig. 3).

Planktonic and benthic foraminifers in the samples are listed in Table 1. The stratigraphic distribution of selected benthic marker species is given in Figure 4.

\section{Local Zonation}

In this section of Hole 605 , we found highly diverse faunas of obvious late Maestrichtian age. The Late Cretaceous section at Site 605 is subdivided into three local biozones (Fig. 3): an upper Racemiguembelina fructicosa Total Range Zone in which $R$. fructicosa is common to abundant; a middle Globotruncana contusa Partial Range Zone, with the top defined by the appearance of $R$. fructicosa; and a lower Globotruncana stuarti Partial Range Zone for which the top is defined by the appearance of $G$. contusa. We did not use Abathomphalus mayaroensis, because this species occurs only in very small numbers in this section.

The $R$. fructicosa Zone is subdivided into an upper Planoglobulina brazoensis Total Range Subzone and a lower Rugoglobigerina scotti Partial Range Subzone in which $R$. fructicosa but not $P$. brazoensis occurs.

This local zonation correlates to the global schemes (e.g., van Hinte, 1976, and Robaszynski et al., 1984) if we use the range of $A$. mayaroensis, which, however, is rare to statistically absent in this section. Its occurrence in Sample 605-71,CC is thought to be due to caving. We conclude that our local $R$. fructicosa Zone represents the global A. mayaroensis Zone. Our local G. contusa and $G$. stuarti zones represent the global Zones UC16 and UC15 of van Hinte (1976), which include the larger part of the G. gansseri Zone of Robaszynski et al. (1984).

The ranges of selected benthic index species such as Bolivinoides draco draco Marsson, $B$. decoratus giganteus Hiltermann and Koch, Bolivina incrassata group, Stensioeina pommerana Brotzen, and Osangularia cordieriana navarroana (Cushman) are given in Figure 4. The range of Bolivinoides draco draco has been corre- 


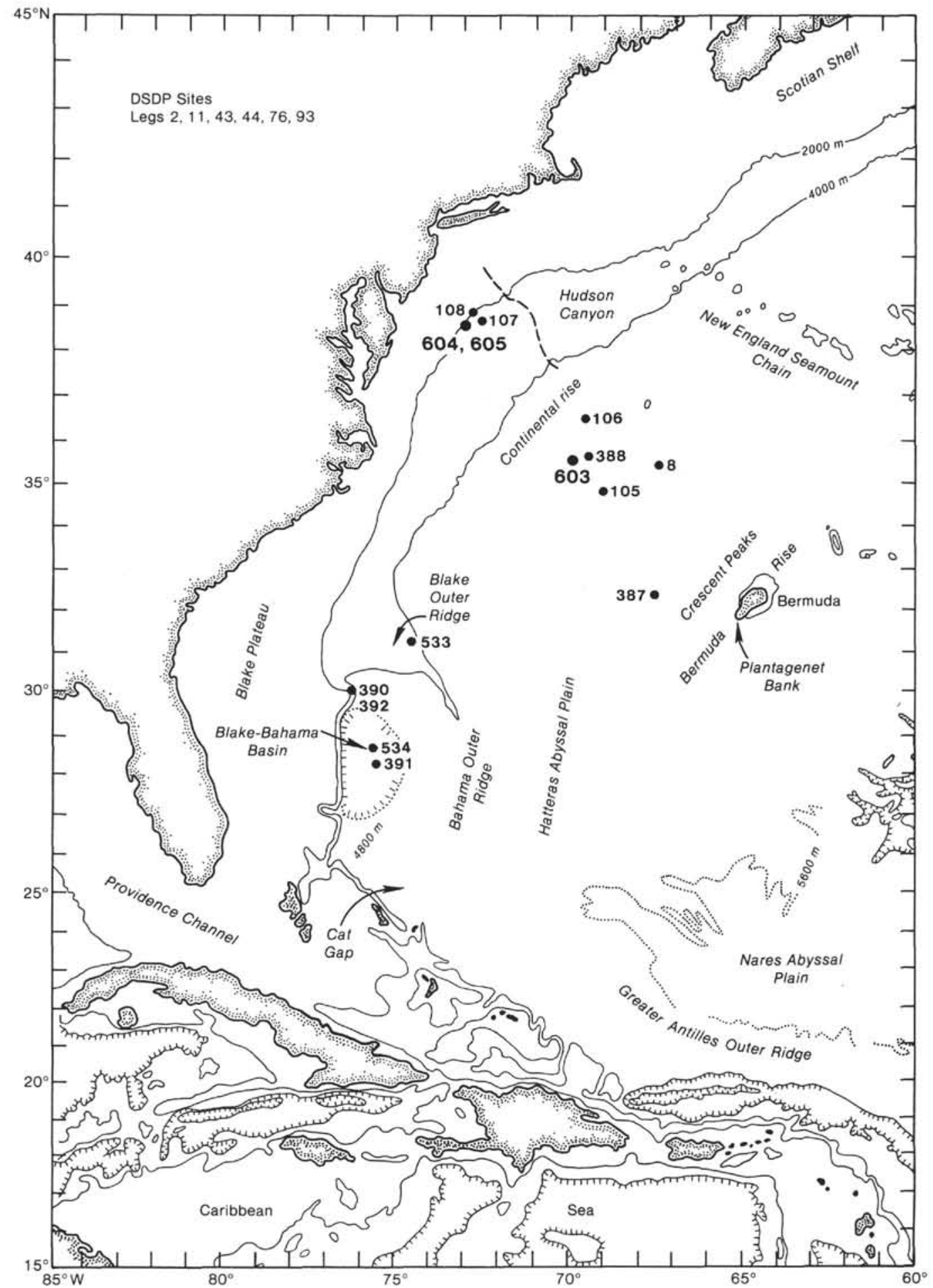

Figure 1. Location of Site 605.

lated with planktonic index species (van Hinte, 1967, 1976 ) and, at Site 605, further indicates that the $R$. fructicosa Zone does indeed represent the latest Maestrichtian.

The local zonation presented here is comparable with those of Cita and Gartner (1971) and McNulty (1979), as shown in Figure 5.

\section{Percentage of Benthic Foraminifers}

Figure 2 shows the percentage of benthic foraminifers in the total foraminiferal fauna for each sample. This percentage (with an average of $4.6 \%$ ) shows little variation throughout the samples, with the distinct exception of the percentages obtained from Samples 605- 


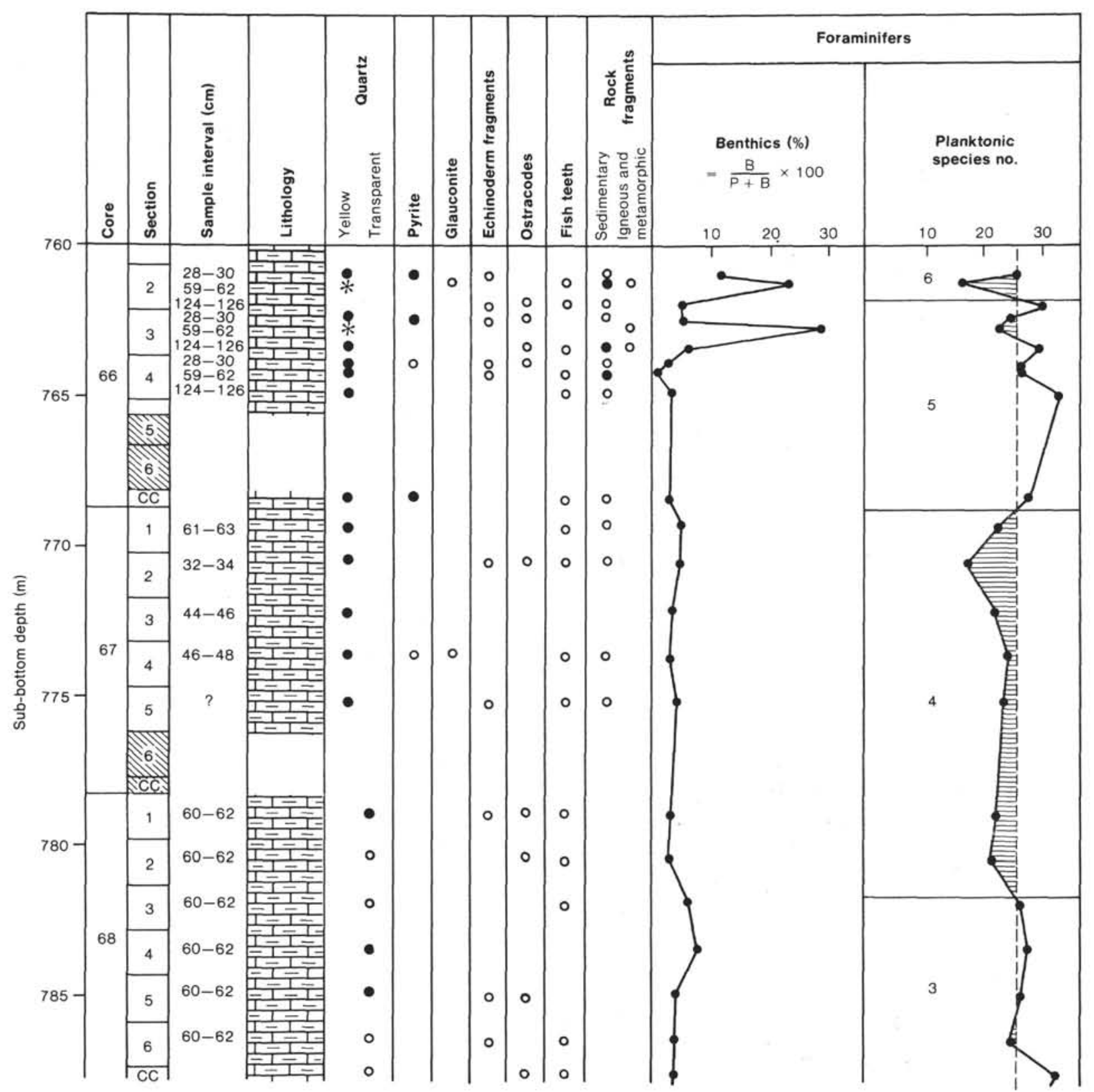

Figure 2. Lithography of Cores 66-71, showing biogenic and lithogenic components in wash residues and the percentage of benthic foraminifers. The sequence is subdivided into six units using planktonic species numbers. Shaded intervals show where species numbers are lower than the overall average.

$66-3,59-62 \mathrm{~cm}, 605-66-2,28-30 \mathrm{~cm}$ and $605-66-2,59-$ $62 \mathrm{~cm}$. These samples contain from $10-30 \%$ benthic foraminifers, which may be indicative of mass transport. The low percentage of benthics is indicative of a pelagic, bathyal paleoenvironment.

\section{Species Number}

The average number of planktonic species in our samples is 25 (Fig. 2). The sequence can be subdivided into smaller units using the planktonic species number. Each unit shows small variations around an average species number within each unit, but, between units species number shifts considerably. It is below 25 species in units 1 ,
4 , and 6 . In unit 6 this corresponds with a high $\%$ benthic peak in Sample 605-66-2, 59-62 cm. The same correspondence, though less pronounced, is found in Sample $605-66-3,59-62 \mathrm{~cm}$. This may point to gravitational processes, which introduced increased numbers of benthic foraminifers in the depositional environment and diluted the planktonic faunas.

Benthic diversity was investigated to the superfamily level (Fig. 6). The results show that the benthic faunas are relatively stable and generally are dominated either by agglutinated forms or by cassidulinids. Agglutinated forms dominate in the upper $(605-66-2,28-30 \mathrm{~cm}$ to $605-$ $67-2,32-34 \mathrm{~cm})$ and lower $(605-69-4,60-62 \mathrm{~cm}$ to $605-$ $71-4,60-62 \mathrm{~cm}$ ) part of the section. 


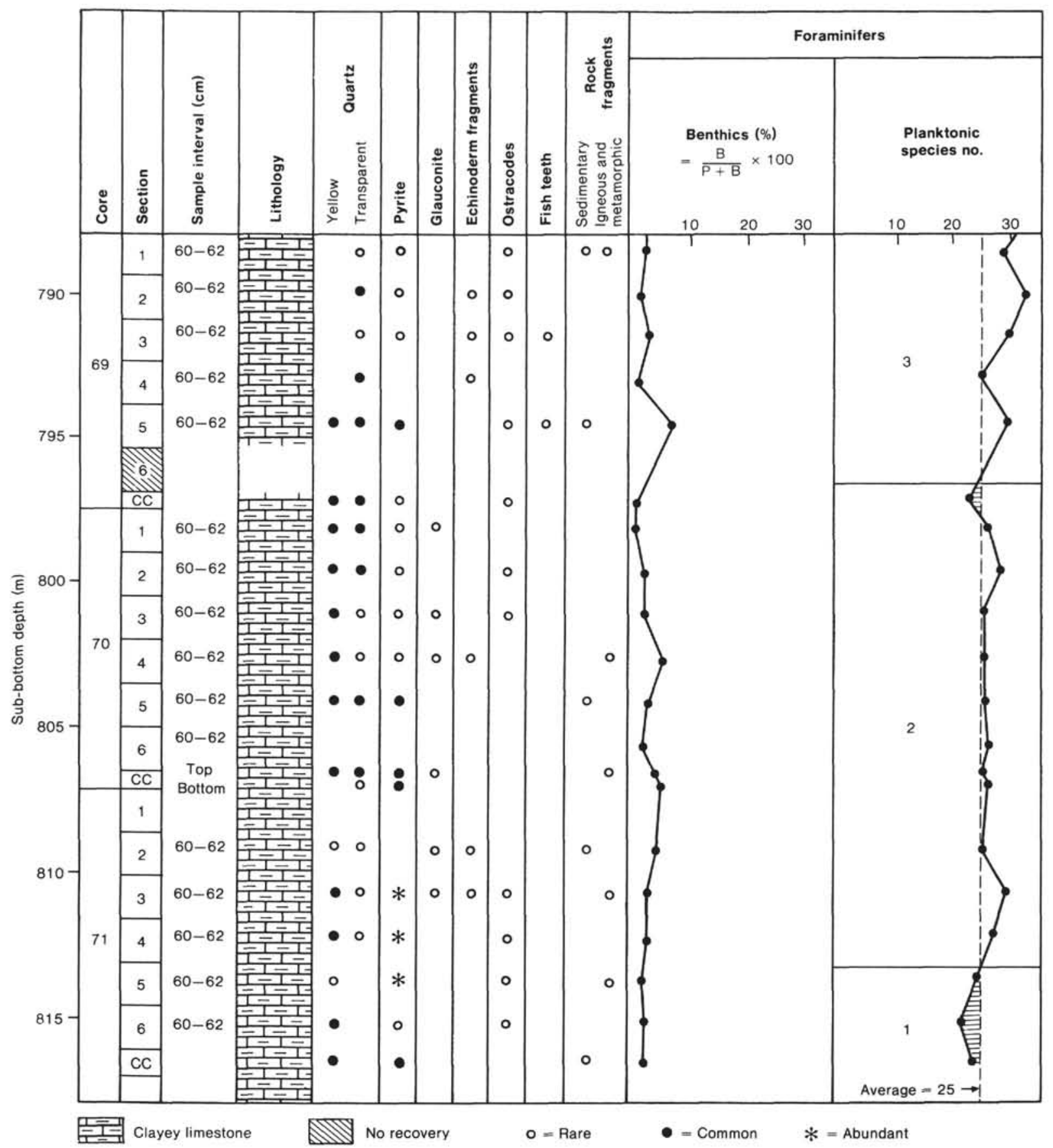

Figure 2. (Continued).

\section{Depth of Deposition}

It is assumed that subsidence caused by lithospheric cooling of the crust was negligible by Maestrichtian time. We derived the paleodepth by using a correction factor of 0.726 , after Hardenbol et al. (1981), on the postMaestrichtian sediments in our section. This gives a paleodepth of $(760+2194)-(0.726 \times 760)=2402 \mathrm{~m}$. The present water depth at Site 605 is $2194 \mathrm{~m}$. The actual paleodepth of the Maestrichtian section would have been somewhat shallower because of post-Maestrichtian compaction of the pre-Maestrichtian section.

\section{Paleoenvironment}

Watermasses are characterized by their foraminiferal fauna in the present and in the past (Bé, 1977; Vincent and Berger, 1981). Nyong (1984), discussing the Late Cretaceous planktonic foraminiferal faunas of the North Atlantic, noted a "transitional" biogeographic province located at $40^{\circ} \mathrm{N}$ (Fig. 7) and characterized by the co-occurrence of "cold"-water species of Rugoglobigerina, Archaeoglobigerina, and Hedbergella and warm-water species of the globotruncanids and heterohelicids, coming from the Tethyan biogeoprovince. 


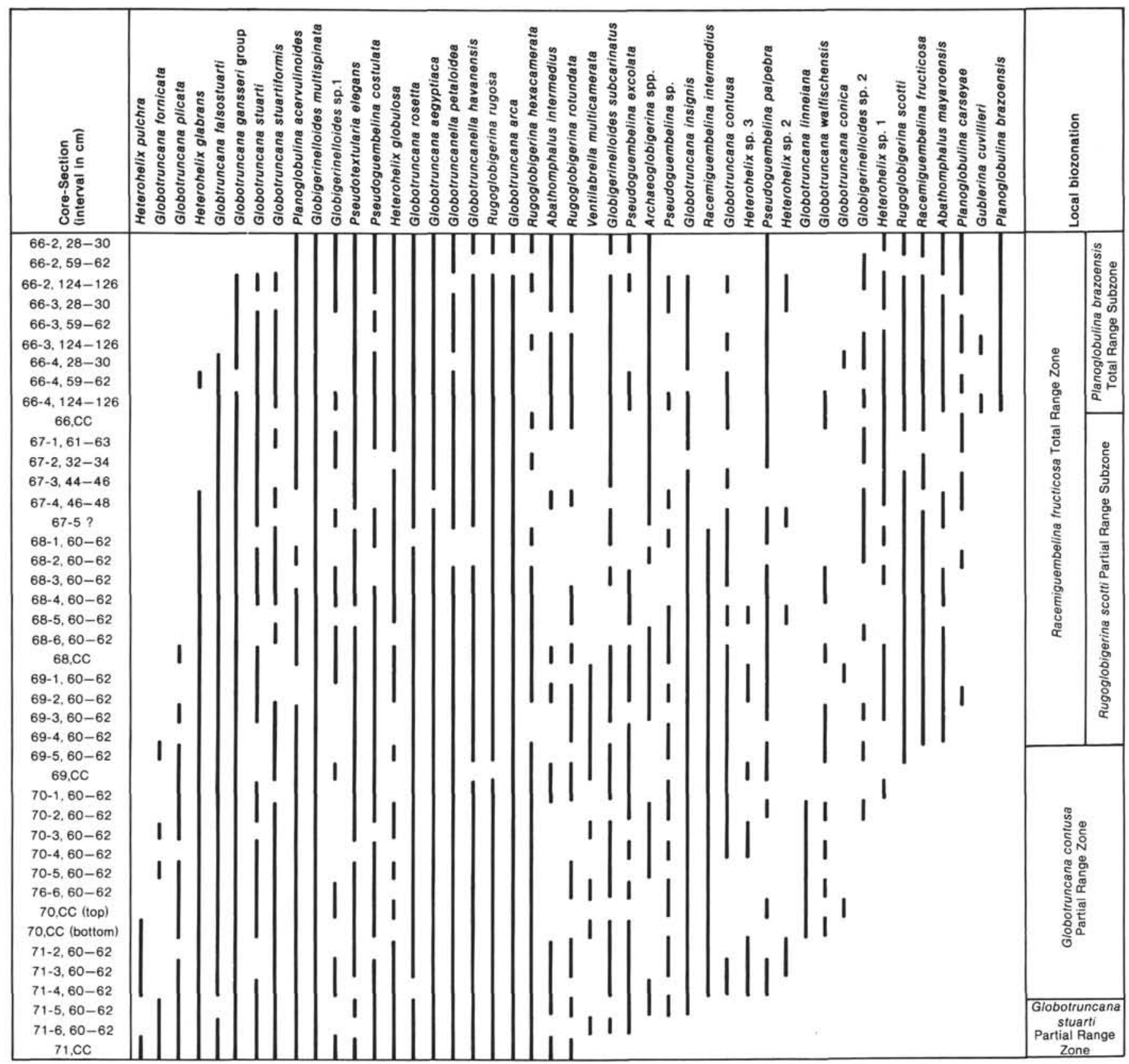

Figure 3. Distribution chart of the planktonic foraminifers from Site 605 , and local biozonation.

The dominant fauna consists of warm-water taxa, but "cold"-water forms are also present at Site 605 . The dominance of the warm-water species suggests that a clockwise circulation late in the Cretaceous in this area brought warm water northward. This circulation pattern is similar to that of the modern North Atlantic. (See Olsson and Wise [this volume] for further discussion of the biogeography of the Upper Cretaceous calcareous plankton at this site.)

A paleodepth of $\sim 2400 \mathrm{~m}$ for our benthic assemblages is consistent with the relative stability of the percentage of benthic foraminifers and the constant relative abundancies of the benthic superfamilies throughout the section (Fig. 6).
The depositional scenario for this section is a gently subsiding continental rise environment over which a northerly surface current flowed.

\section{TAXONOMIC REMARKS}

\section{Genus GLOBOTRUNCANA Cushman, 1927 \\ Globotruncana aegyptiaca Nakkady (Pl. 1, Fig. 1-3)}

Globotruncana aegyptiaca Nakkady, 1950, p.690, pl. 80, fig. 20, is an abundant species in our samples and dominates the planktonic foraminiferal faunas in this section. It shows variation in number of chambers in the last whorl (3-6), in the inflation of the chambers, and in the convexity of the spiral side, most specimens having a flat sprial side. Globotruncana aegyptiaca is very close to $G$. ventrico- 
Table 1. Maestrichtian foraminifers, Hole 605.

1. Most common planktonic species

Globotruncana aegyptiaca Nakkady

G. arca (Cushman)

G. falsostuarti Siga

$G$. insignis Gandolf

$G$, rosetta (Carsey)

Globotruncanella havanensis (Voorwijk)

G. petaloidea (Gandolfi)

Rugoglobigerina rugasa (Plummer)

Heterohelix globulosa (Ehrenberg)

Planoglobulina acervulinoides (Egger)

Pseudotextularia elegans (Rzehak)

Pseudoguembelina excolata (Cushman)

$P$ costulata (Cushman)

Globigerinelloides multispinata (Lalicker)

G. subcarinatus (Brönnimann)

Globigerinelloides spp.

2. Less common planktonic species

Abathomphalus mayaroensis (Bolli)

A. intermedius (Bolli)

Globotruncana conica White

G. contusa (Cushman)

G. fornicata Plummer

G. gansseri Bolli

G. plicata White

G. linneiana (d'Orbigny)

G. stuarti (de Lapparent)

G. stuartiformis Dalbiez

G. walfischensis Todd

Rugoglobigerina hexacamerata Brönnimann

$R$. rotundata Brönnimann

R. scotti (Brönnimann)

Planoglobulina brazoensis Martin

P. carseyae (Plummer)

Racemiguembelina fructicosa (Egger)

$R$. intermedia (de Klasz)

Ventilabrella multicamerata de Klasz

Heterohelix glabrans (Cushman)

$H$. pulchra (Brotzen)

Gublerina cuvillieri Kikoine

Pseudoguembelina palpebra Brönnimann and Brown Pseudoguembelina sp. 1

Heterohelix spp.

Hedbergella spp.

3. Common benthic genera

\section{Bathysiphon}

Reophax

Ammodiscus

Glomospira

Textularia

Spiroplectammin

Clavulina

Pseudobolivina

Dorothia

Haplophragmoides

Rzehakina

Trochammine

Lagena

Nodosaria

Dentalina

Astacolus

Pyrulina

Lenticulina

Pyramidina

Pseudouvigerina

Bolivina

Bolivinoides

Pleurostomella

Anomalinoides

Gavelinella

Gyroidinoides

Gyroidina

Pullenia

Conorotalites

Albamina

Osangulario

Quadrimorphina

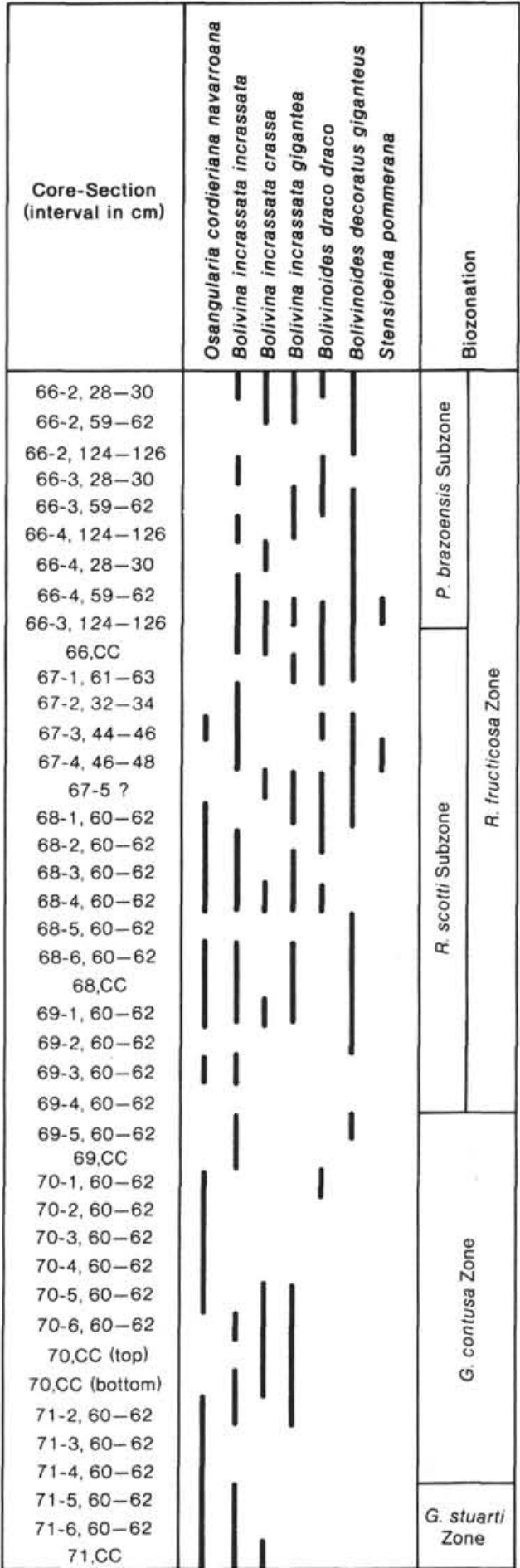

Figure 4. Distribution chart of selected age-diagnostic benthic species.

$s a$, but its chambers increase more rapidly in size. Some specimens from Sample 605-69-2, 60-62 cm to Sample 605-71,CC, resemble

G. gagnebini Tilev (sensu Postuma, 1962) in having all chambers

$(3-5)$ inflated on the spiral side and rugosite on both sides.

Globotruncana arca (Cushman)

$$
\text { (P1. 1, Figs. 4-6) }
$$

Pulvinulina arca Cushman, 1926, p. 43, pl. 3, fig. 1 .

Globotruncana arca is present in all samples, with the exception of Sample $605-66-2,59-62 \mathrm{~cm}$. In this fauna, most specimens of $G$. 


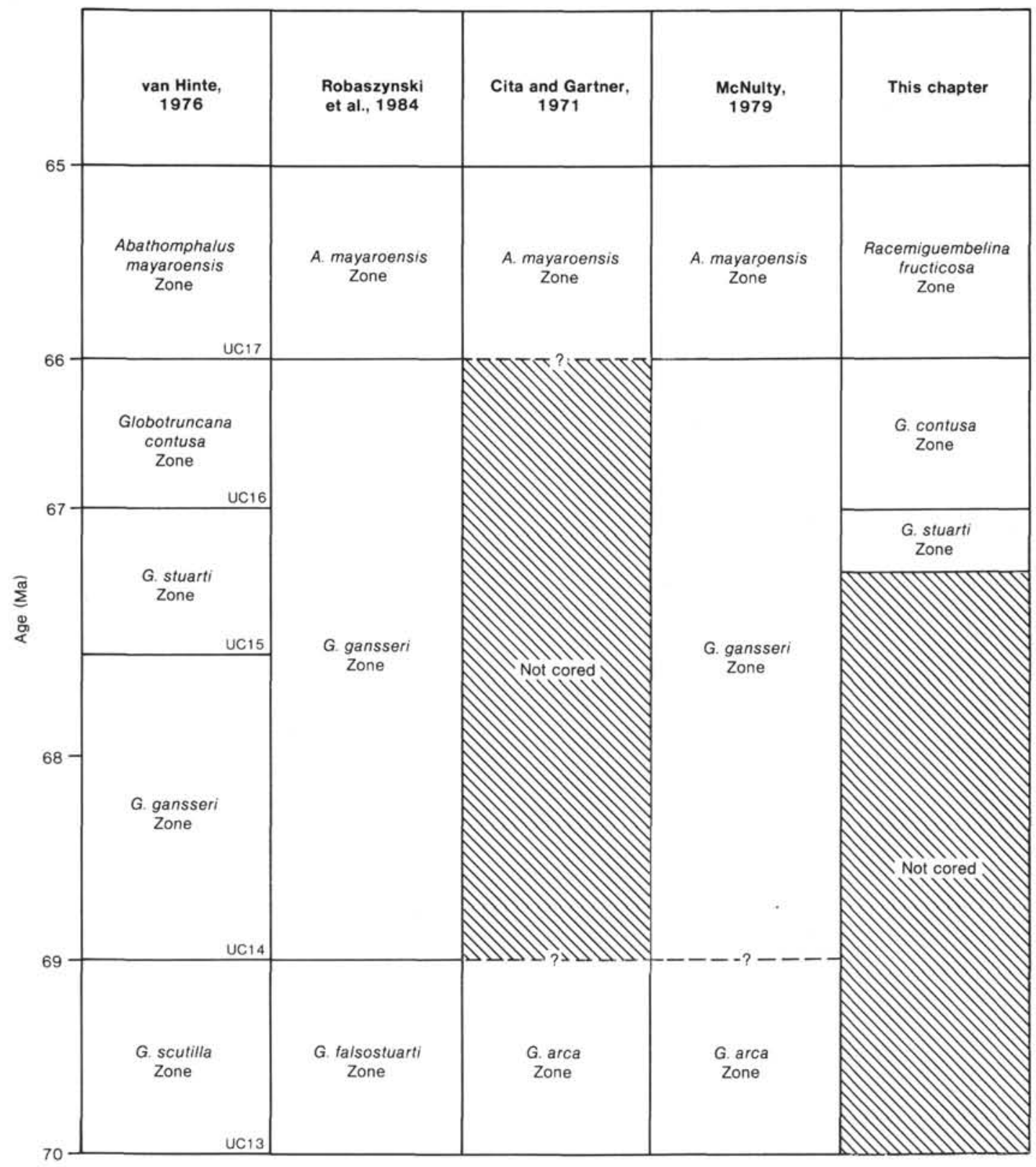

Figure 5. Local biozonation at Site 605, compared with biozonations of Site 10, Leg 2 (Cita and Gartner, 1971), Site 384, Leg 43 (McNulty, 1979), and global schemes of van Hinte, 1976, and Robaszynski et al., 1984.

arca have only 5-6 chambers in the last whorl. A few specimens lack a second keel on the final chambers, like $G$. orientalis El Naggar, which has here been included in G. arca.

\section{Globotruncana conica White}

$$
\text { (Pl. 3, Figs. 4-6) }
$$

A few specimens of Globotruncana conica White (1928, p. 285, pl. 38, fig. 7a-c) were found in Samples 605-69-1, 60-62 cm, and 605$70, \mathrm{CC}$ (top); they are easily recognized by their high trochospire, smooth, circular outline, single keel, and flat umbilical side.

\section{Globotruncana contusa (Cushman)}

$$
\text { (Pl. 4, Figs. 4-9) }
$$

Pulvinulina arca Cushman var. contusa Cushman, 1926, p. 23. Globotruncana (Globotruncana) contusa (Cushman) sp. patelliformis Gandolfi, 1955, p. 54, pl. 4, fig. 2a-c.
Globotruncana contusa occurs in low numbers in this section, except for Sample 605-66-4, 124-126 cm, where it is abundant. This species is characterized by a moderately high to high trochospire, and a polygonal outline. For a discussion of the taxonomic problems involving this species we refer to Robaszynski et al.(1984). We consider $G$. patelliformis to fall within the morphological range of $G$. contusa.

\section{Globotruncana falsostuarti Sigal}

(Pl. 1, Figs. 7, 8)

Globotruncana faisostuarti Sigal (1952, p. 43, fig. 6) is common at the base of the section and becomes rare toward the top. It is absent in the upper five samples. Globotruncana falsostuarti has two keels, which are typically closer together in the middle of each chamber, the umbilical keel being usually less well developed or absent on the last few chambers. Specimens with fully developed keels are common in the lower part of the section, whereas the number of 


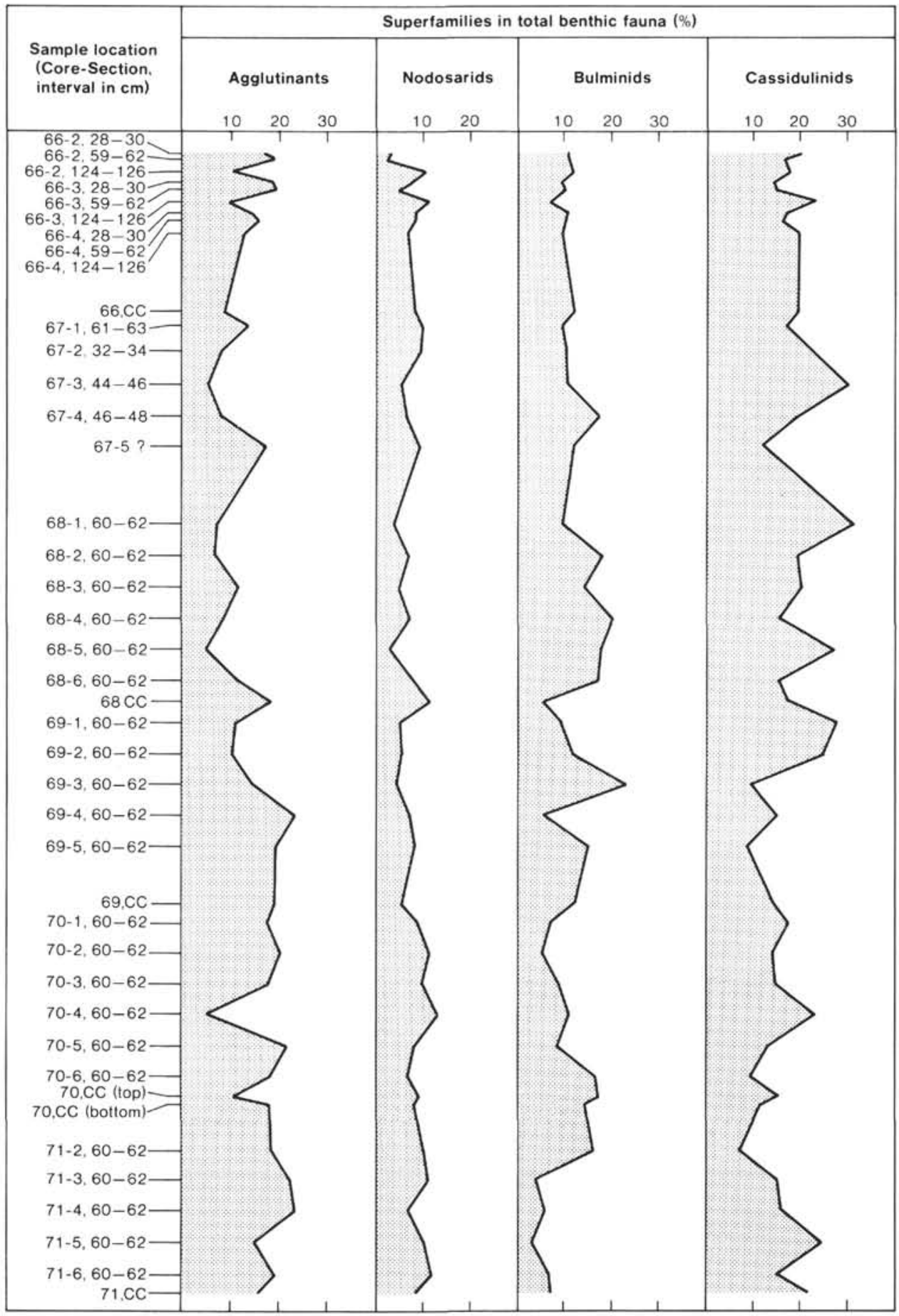

Figure 6. Percentages of benthic foraminiferal superfamilies in total foraminiferal fauna from Site 605 .

specimens lacking an umbilical keel on the final chamber increases toward the upper part of the section.

\section{Globotruncana fornicata Plummer}

(Pl. 4, Figs. 1-3)

Globotruncana fornicata Plummer (1931, p. 130, pl. 13, fig. 4a-c) rarely occurs in the lower part of the section. Specimens are small, with low to moderately high trochospire, and a subpolygonal to rounded peripheral outline.
Globotruncana gansseri Bolli

(Pl. 3, Figs. 1-3; Pl. 7, Figs. 1-6)

Globotruncana gansseri Bolli, 1951, pl. 35, figs. 1-3.

Globotruncana lugeoni Tilev var. angulata Tilev, 1951, fig. 1a-c. 13a-c. Globotruncana (Globotruncana) wiedenmayeri wiedenmayeri Gandolfi, 1955, pl. 7, fig. 4a-c.

Globotruncana (Globotruncana) rosetta (Carsey) sp.pettersi Gandolfi, 1955, p. 68, pl. 6, fig. 3a-c.

Globotruncana gansseri ranges throughout the section in low numbers. Globotruncana gansseri sensu Robaszynski et al. (1984) is 


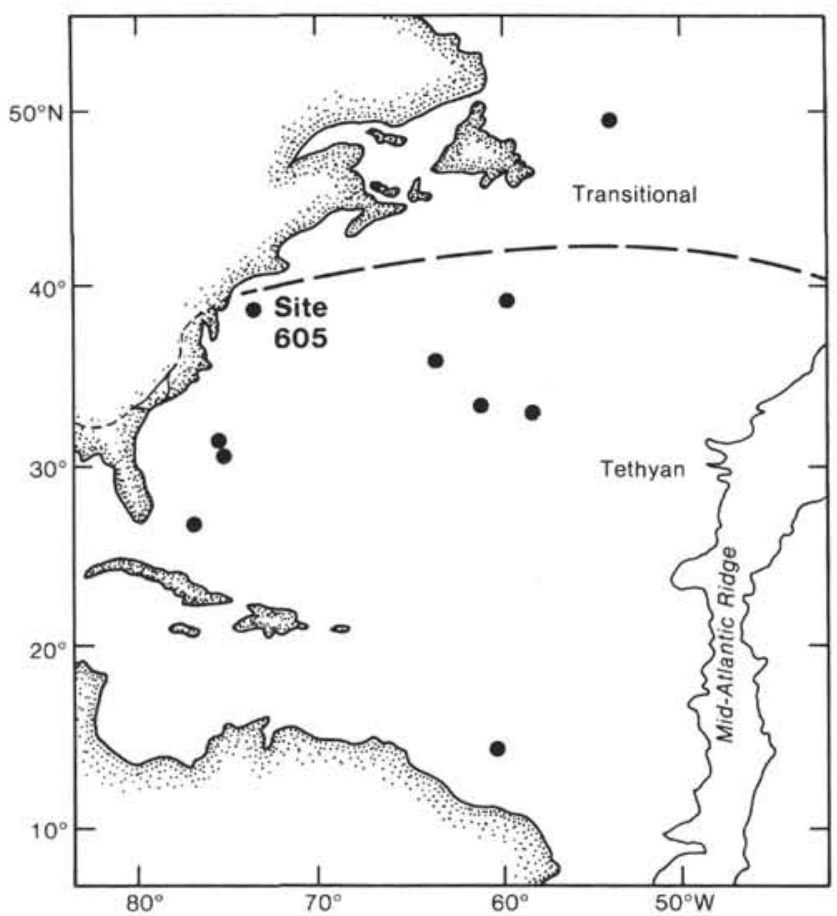

Figure 7. The position of two biogeographic provinces in the western North Atlantic in the Late Cretaceous, modified after Nyong (1984).

only present in Samples 605-67-1, 61-63 cm to 605-68-2, 60-62 cm, where it is abundant. It is characterized in these samples by the presence of one keel, sometimes with a row of pustules parallel to the keel on the umbilical side, an almost flat spiral side, and rugosities on the earlier chambers of the last whorl. Globotruncanita angulata (Tilev) and Globotruncanita pettersi (Gandolfi) sensu Robaszynski et al. (1984) are considered synonyms of Globotruncana gansseri in this study. These smooth forms range throughout the section, whereas $G$. gansseri s.s. appears only in the local Racemiguembelina fructicosa Zone. Separating these forms in this section results in a very short range of $G$. gansseri.

\section{Globotruncana insignis Gandolfi}

(Pl. 2, Figs. 1, 2)

Globotruncana (Globotruncana) rosetta (Carsey) ssp. insignis Gandolfi, 1955 , p. 67 , pl. 6 , fig. $2 a-c$.

Globotruncana insignis is a common species in this section. Most specimens have a flat spiral side and are slightly lobate. The species is distinguished from $G$. gansseri by the acute peripheral angle and narrow umbilicus with tegilla in the final chambers.

\section{Globotruncana linneiana (d'Orbigny)}

(Pl. 2, Figs. 3-5)

Rosalina linneiana d'Orbigny, 1839, p. 101, pl. 5, fig. 10-12.

A few specimens of Globotruncana linneiana were encountered in the lower part of the section. G. linneiana is easily recognized by its lobate outline, flattened lateral view, and by the widely spaced keels on all chambers of the last whorl.

\section{Globotruncana plicata White}

Globotruncana conica White var. plicata White, 1928, p. 285, Globotruncana plicata is common in the lower part of the section. It differs from $G$. contusa in having a lobate peripheral outline, smaller number of whorls, and depressed sutures between the final chambers on the spiral side.
Globotruncana rosetta (Carsey)

(PI. 1, Figs. 9-11; Pl. 2, Figs. 6, 7)

Globigerina rosetta Carsey, 1926, p. 44, pl. 5, fig. 3a-b.

Globotruncana arca (Cushman) var. esnehensis Nakkady, 1950, p. 690, pl. 90, figs. 23-26.

Globotruncana dupeublei Caron, Gonzalez Donoso, Robaszynski, and Wonders, 1984, p. 188, pl. 7m, fig. 1-2 in Robaszynski et al. (1984).

Globotruncana rosetta is a common species in most samples. It has a slightly convex to flat spiral side, and a convex umbilical side. A second keel is present on the earlier chambers of the last whorl, but absent on the final chambers. As such, it is in the center of a morphological series with $G$. dupeublei/G. insignis/G. esnehensis on the single-keeled end, and $G$. orientalis/G. ventricosa on the double-keeled end. It differs from $G$. falsostuarti in that the two keels are not close together in the middle of each chamber.

\section{Globotruncana stuarti (de Lapparent)}

(PI. 3, Figs. 10, 13)

Rosalina stuarti de Lapparent, 1918, p. 11, pl. 4, lower three figures. Globotruncana stuarti occurs infrequently and in low numbers in our samples; its test is often damaged. This bioconvex species has subrectangular spiral chambers in the last whorl.

\section{Globotruncana stuartiformis Dalbiez (Pl. 3, Figs. 11, 12)}

Globotruncana (Globotruncana) elevata Brotzen, ssp. stuartiformis Dalbiez, 1955, p. 169, pl. 10a-c.

A few specimens of Globotruncana stuartiformis were found in our samples. Typically, they have an asymmetrical profile in lateral view, in that the umbilical side is more highly convex than the spiral side, and triangularly shaped last chambers on the spiral side.

\section{Globotruncana walfischensis Todd}

$$
\text { (Pl. 4, Figs. 10-12) }
$$

Globotruncana walfischensis Todd (1970, p. 153, pl. 5, fig. 8a-b) appears in low numbers throughout the section. It is characterized by small size, circular outline, and concavo-convex shape, and by weakly developed keels on the final chambers.

Genus GLOBOTRUNCANELLA Reiss, 1957, emended Robaszynski et al., 1984

Globotruncanella havanensis (Voorwijk)

(Pl. 5, Figs. 1, 2)

Globotruncana havanensis Voorwijk, 1937, p. 195, pl. 1, figs. 25, 26, 29.

Globotruncanella havanensis (Voorwijk) van Hinte, 1963, p. 94, pl. 10, fig. 3 , pl. 11, figs, $4-5$, pl. 12, fig. 1 (redescription of holotype)

Globotruncanella havanensis is almost always present in our samples. It is characterized by its lobate outline, globular chambers in the earlier whorls, and flattened chambers in the last whorl, which tilt towards the umbilicus. A few specimens show a true keel, resembling G. pschadae Keller.

\section{Globotruncanella petaloidea (Gandolfi)}

$$
\text { (Pl. 5, Figs. 3-5) }
$$

Globotruncana (Rugoglobigerina) petaloidea Gandolfi ssp. petaloidea Gandolfi, 1955, p. 52, pl. 3, fig. 13a-c.

Globotruncanella petaloidea is present in most samples. It has a strongly lobate outline, and always four chambers in the last whorl; these chambers are less pinched in lateral view than those of $G$. havanensis.

Genus ABATHOMPHALUS Bolli, Loeblich, and Tappan, 1957

\section{Abathomphalus intermedius (Bolli)}

(Pl. 5, Figs. 6-7)

Globotruncana intermedia Bolli, 1951, pl. 35, figs. 7-9.

A few specimens of Abathomphalus intermedius were found in this section. $A$. intermedius can be distinguished from $A$. mayaroensis 
by its smaller size, convex spiral side, and weakly developed keels. Intermediate forms between $A$. mayaroensis and $A$. intermedius are present.

\section{Abathomphalus mayaroensis (Bolli)}

(Pl. 5, Figs. 8-10)

Globotruncana mayaroensis Bolli, 1951, pl. 35, figs. 10-12.

Abathomphalus mayaroensis is very rare in the upper part of the section. The few specimens found are easily recognized by their two widely space keels and flat spiral side.

Genus ARCHAEOGLOBIGERINA Pessagno, 1967 Archaeoglobigerina spp.

(Pl. 9, Figs. 12-14)

These species occur throughout the section. They differ from the rugoglobigerinids in lacking costellae or pustules arranged in a particular pattern.

\section{Genus RUGOGLOBIGERINA Brönnimann, 1952 \\ Rugoglobigerina hexacamerata Brönnimann}

$$
\text { (Pl. 7, Fig. 7, 8) }
$$

Rugoglobigerina (Rugoglobigerina) reicheli hexacamerata Brönnimann, 1952 , p. 23 , pl. 2 , figs. $10-12$.

Rugoglobigerina hexacamerata occurs rarely in most samples. It can be distinguished from $R$. rugosa by its slower increase in chamber size, and by the presence of 6-7 chambers in the last whorl.

\section{Rugoglobigerina rotundata Brönnimann}

(Pl. 6, Figs. 1-3)

Rugoglobigerina (Rugoglobigerina) rugosa rotundata Brönnimann, 1952 , p. 43, pl. 4, figs. 7-9.

Rugoglobigerina rotundata occurs infrequently and in low numbers throughout the section. It is characterized by a high trochospire, and is much larger in size than other species of this genus.

\section{Rugoglobigerina rugosa (Plummer)}

$$
\text { (Pl. 6, Figs. 4-6) }
$$

Globigerina rugosa Plummer, 1926, p. 38, pl. 2, fig. 10a.

This is the most common rugoglobigerinid in our section. It is characterized by its flat sprial side and rapidly increasing chamber size. It has 4 to 5 chambers in the last whorl.

\section{Rugoglobigerina scotti (Brönnimann)}

(Pl. 6, Figs. 7-12)

Trinitella scotti Brönnimann, 1952, p. 57, pl. 4, fig. 4-6.

Rugoglobigerina scotti occurs in the upper part of the section, where it is abundant in Samples 605-66-4, 28-30 cm to 605-66-4, 124-126 $\mathrm{cm} . R$. scotti is characterized by the compressed chambers, varying from $4-6$, in the last whorl. The four-chambered types appear from Sample 605-68-4, 60-62 cm upward, the 5-6-chambered types appear throughout its range.

\section{Genus HETEROHELIX Ehrenberg, 1843 \\ Heterohelix glabrans (Cushman)}

$$
\text { (Pl. 7, Fig. 9) }
$$

Guembelina glabrans Cushman, 1938, p. 15, pl. 3, fig. 1a-2.

Heterohelix glabrans is common in the lower part of the section. It has a flattened biserial test with the chambers increasing rapidly in size.

\section{Heterohelix globulosa (Ehrenberg)}

$$
\text { (Pl. 7, Fig. 11) }
$$

Textularia globulosa Ehrenberg, 1840, p. 135, pl. 4, figs. 1-8.

Heterohelix globulosa is present in almost every sample. Some specimens may resemble $\mathrm{H}$. striata (Ehrenberg) in possessing striae.

\section{Heterohelix pulchra (Brotzen)}

$$
\text { (Pl. 7, Fig. 10) }
$$

Guembelina pulchra Brotzen, 1936, p. 121, pl. 9, figs. 2, 3.

Heterohelix pulchra can be found in the lowermost samples. It is characterized by its small size and reniform chambers.

\section{Heterohelix sp. 1}

(Pl. 8, Fig. 3)

Heterohelix sp. 1 occurs in the upper part of the section, in low numbers. This species resembles $H$. pulchra, but differs in its larger size and greater number of chambers.

\section{Heterohelix sp. 2}

(Pl. 8, Fig. 4)

Heterohelix sp. 2 is a rare species, easily recognized because the last chamber is elongated in the direction of growth.

\section{Heterohelix sp. 3 \\ (PI. 8, Fig. 8)}

Heterohelix sp. 3 is a rare species in the lower part of the section. It is characterized by its small size and the slow increase in chamber size. It resembles $H$. moremani (Cushman).

\section{Genus VENTILABRELLA Cushman, 1928 Ventilabrella multicamerata de Klasz$$
\text { (Pl. 8, Fig. 9) }
$$

Ventilabrella multicamerata de Klasz (1953, p. 230, pl. 5, fig. 1a-b) is a rare species in the lower part of the section. It is characterized by vermicular ornamentation on the early chambers and by indistinct chambers in the later portion.

\section{Genus PSEUDOGUEMBELINA Brönnimann and Brown, 1953}

\section{Pseudoguembelina costulata (Cushman)}

(Pl. 8, Fig. 5)

Guembelina costulata Cushman, 1938, pp. 16-17, pl. 3, figs. 7-9.

Pseudoguembelina costulata is a common species in this section. It differs from $P$. excolata (Cushman) by its smaller size, more slender test, and finer striations.

\section{Pseudoguembelina excolata (Cushman)}

$$
\text { (Pl. 8, Fig. 6) }
$$

Guembelina excolata Cushman, 1926, p. 20, pl. 2, fig. 9.

Pseudoguembelina excolata occurs infrequently throughout the section. It is characterized by its coarse striae.

\section{Pseudoguembelina palpebra Brönnimann and Brown} (Pl. 8, Fig. 11)

Pseudoguembelina palpebra Brönnimann and Brown (1953, p. 155 , figs. $9 \mathrm{a}-10 \mathrm{~b}$ ) can be found throughout the section in low numbers. It is characterized by its inflated chambers, which, in the early part, increase rapidly in size.

\section{Pseudoguembelina sp. 1}

(Pl. 8, Fig. 7)

Pseudoguembelina sp. 1 is a rare species in this section. It differs from Pseudoguembelina palpebra in being more slender and in possessing less inflated chambers.

\section{Genus PSEUDOTEXTULARIA Rzehak, 1891 \\ Pseudotextularia elegans (Rzehak)}

(Pl. 8, Figs. 1, 2)

Cuenolina elegans Rzehak, 1891, p. 4.

Pseudotextularia elegans is common throughout the section. It is characterized by its large basal aperture, slender biserial view, and triangular side view.

\section{Genus RACEMIGUEMBELINA Montanaro Gallitelli, 1957}

\section{Racemiguembelina fructicosa (Egger)}

(PI. 8, Fig. 13)

Guembelina fructicosa Egger, 1899, p. 35, pl. 14, figs. 8, 9.

Racemiguembelina fructicosa is abundant in the upper part of the section. It has a conical shape and is therefore easily distinguished from other species. 


\section{Racemiguembelina intermedia (de Klasz)}

(Pl. 8, Fig. 12)

Pseudotextularia intermedia de Klasz, 1953, p. 231-232, pl. 5, fig. $2 \mathrm{a}-\mathrm{c}$.

Racemiguebelina intermedia ranges from Samples 605-71-4, 60-62 cm to $605-68-1,60-62 \mathrm{~cm}$. It is characterized by a biserial test with accessory aperatures only between the last chambers. It is morphologically close to Pseudotextularia elegans.

Genus PLANOGLOBULINA Cushman, 1927, emend. Martin, 1972 Planoglobulina acervulinoides (Egger)

(PI. 8, Fig. 10)

Pseudotextularia acervulinoides (Egger) Cushman, 1926, p. 17, pl. 2, fig. 5 .

Planoglobulina acervulinoides is common throughout the section. This species has a flabelliform test and differs from Planoglobulina brazoensis Martin in having a more planar test and more widely spaced striations.

\section{Planoglobulina brazoensis Martin}

(Pl. 9, Fig. 1-3)

Planoglobulina brazoensis Martin (1972, pp. 82-83, pl. 3, fig. 7a-c, pl. 4, fig. 1a-2) occurs only in Core 66, the uppermost part of the section. Its flabelliform test is inflated in the early portion and has globular chambers in the multiserial portion, with widely spaced, coarse striae.

\section{Planoglobulina carseyae Plummer}

Ventilabrella carseyae Plummer, 1931, p. 178, pl. 9, fig. 9a-b.

Planoglobulina carseyae is relatively rare species in the upper samples. This species differs from $P$, brazoensis in having more chambers in the biserial portion; these chambers increase more slowly in size and have finer striations.

\section{Genus GLOBIGERINELLOIDES Cushman and ten Dam, 1948 Globigerinelloides multispinata (Lalicker)}

(Pl. 9, Figs. 4, 5)

Biglobigerinella multispinata Lalicker, 1948, p. 624, pl. 92.

Globigerinelloides multispinata is common in all samples. It varies in the number of chambers in the last whorl (4-6) and the degree of inflation of chambers, and may develop a bipartite primary aperture that is occasionally covered by thin-walled chambers. $G$. messinae (Brönnimann) is considered a junior synonym.

\section{Globigerinelloides subcarinatus (Brönnimann)}

(Pl. 9, Figs. 6, 7)

Globigerinella messinae ssp subcarinata Brönnimann, 1952, p. 44, pl. 1, figs. 10,11

Globigerinelloides subcarinatus ranges through the whole section. Its planispiral test has a last whorl with 5 chambers and a pinched periphery in lateral view. Some specimens tend to develop an elongated last chamber.

\section{Globigerinelloides sp. 1}

$$
\text { (Pl. 9, Fig. 10) }
$$

A few specimens of Globigerinelloides sp. 1 were encountered. Its test has 6-7 chambers in the last whorl; these increase slowly in size and are pinched in lateral view.

\section{Globigerinelloides sp. 2}

$$
\text { (Pl. 9, Figs. 8, 9) }
$$

This species is present throughout the section in low numbers. It differs from Globigerinelloides sp. 1 in having more chambers in the last whorl; they are rounded in lateral view.

\section{Genus GUBLERINA Kikoine, 1948 \\ Gublerina cuvillieri Kikoine \\ (Pl. 9, Fig. 11)}

Gublerina cuvillieri Kikoine (1948, p. 26, pl. 2, fig. 10) is a very rare species in this section. It has a biserial test, in which the final chambers are separated by a nonseptal portion.
Genus HEDBERGELLA Brönnimann and Brown, 1958

Hedbergella spp.

Small specimens of Hedbergella are present throughout the section in the $75-125-\mu \mathrm{m}$ fraction.

\section{ACKNOWLEDGMENTS}

The authors wish to thank J. A. Postuma for giving his generous advice on planktonic foraminifers and his critisism, and J. E. van Hinte for providing us with the samples and critically reading the manuscript. We are greatly indebted to Saskia Kars for helping us operating the SEM at the Free University, Amsterdam, and to the shipboard party of Leg 93. We appreciate the reviews of this manuscript provided by James C. Ingle, Jr., William V. Sliter, and Dean A. Dunn.

\section{REFERENCES}

Bé, A. W. H., 1977. An ecological, zoographic and taxonomic review of recent planktonic foraminifera. In Ramsay, A. T. S. (Ed.), Oceanic Micropaleontology (Vol. 1): London (Academic Press), 1-100.

Bolli, H. M., 1951. The genus Globotruncana in Trinidad, B. W. I. J. Paleontol. 25(no. 2):187-199.

Bolli, H. M., Loeblich, A. R., and Tappan, H., 1957. Planktonic foraminiferal families Hantkeninidae, Orbulinidae, Globorotaliidae and Globotruncanidae. In Loeblich, A. R., et al. (Eds.), Studies in Foraminifera. U.S. Nat. Mus. Bull., 215:51-60.

Brönnimann, P., 1952. Globigerinidae from the Upper Cretaceous (Cenomanian-Maastrichtian) of Trinidad, B. W. I. Bull. Am. Paleontol., 34(no. 140):1-70.

Brönnimann, P., and Brown, N. K., 1953. Observations on some planktonic Heterohelicidae from the Upper Cretaceous of Cuba. Contrib. Cushman Lab. Foraminiferal Res., 4(no. 4):150-160.

1958. Hedbergella, a new name for a Cretaceous planktonic foraminiferal genus. Washington J. Sci., 48(no. 1):15-17.

Brotzen, F., 1936. Foraminifera aus dem schwedischen alttertiären Senon von Erikdal in Schonen. Sver. Geol. Unters., Ser. C, 396: 1-206.

Carsey, D. O., 1926. Foraminifera of the Cretaceous of Central Texas. Texas Univ. Bull., No. 2612.

Cita, M. B., and Gartner, S., 1971. Deep sea Upper Cretaceous from the western North Atlantic. In Farinacci, A. (Ed.), Proc. II Planktonic Conf, Roma, 1970 (Vol. 1): Rome Edizioni (Tecnoscienza), 287-319.

Cushman, J. A., 1926. Some foraminifera of the Mendez Shale of eastern Mexico. Contrib. Cushman. Lab. Foraminiferal Res., 2(no. 1):16-24.

1927. An outline for a re-classification of the foraminifera. Contrib. Cushman Lab. Foraminiferal Res., 3(no. 2):1-105.

1928. Additional genera of the foraminifera. Contrib. Cushman Lab. Foraminiferal Res., 4(no. 1):1-10.

1938. Cretaceous species of Guembelina and related genera. Contrib. Cushman Lab. Foraminiferal Res., 14:2-28.

Cushman, J. A., and ten Dam, A., 1948. Globigerinelloides, a new genus of the Globigerinidae. Contrib. Cushman Lab. Foraminiferal Res., 4(no. 2):42-43.

Dalbiez, F., 1955. The genus Globotruncana in Tunisia. Micropaleontology., 1(no. 2):161-171.

de Klasz, J., 1953. Einige neue oder wenig bekannte Foraminiferen aus der helvetischen Oberkreide der Bayerischen Alpen, südlich Traunstein (Oberbayern). Geol. Bavarica, 17:223-239.

de Lapparent, J., 1918. Etude lithologique des terrains crétacés de la région d'Hendaye. Mem. L'Explic. Carte Geol. Detail. France, pp. $1-155$.

d'Orbigny, A., 1839. Foraminifères. In de la Sagra, R., Histoire physique, politique et naturelle de l'île de Cuba: Paris A. (Bertrand), pp. 1-224.

Egger, J. G., 1899. Foraminiferen und Ostracoden aus den Kreidemergeln der oberbayerischen Alpen. Abh. Bay. Akad. Wiss., MathPhys. Kl., 21:1-230.

Ehrenberg, C. G., 1840. Die Bildung der europäischen, libyschen, und arabischen Kreidefelsen und des Kreidemergels aus mikroskopischen Organismen. Abh. Preuss. Akad. Wiss. Berlin, Phys.-Math. Kl., pp. 1-91.

1843. Verbreitung und Einfluss des mikroskopischen Lebens in Süd- und Nordamerika. Abh. K. Akad. Wiss. Berlin, Phys.Math. Kl., pp. 291-446. 
Gandolfi, F., 1955. The genus Globotruncana in northeastern Colombia. Bull. Am. Paleontol., 36(no. 155):1-118.

Hardenbol, J., Vail, P. R., and Ferrer, J., 1981. Interpreting palaoenvironments, subsidence history and sealevel changes of passive margins from seismic- and biostratigraphy. Oceanol. Acta, Proc. 26 Int. Geol. Congr. Geology of Continental Margins Symposium, Paris, pp. 33-34.

Kikoine, J., 1948. Les Heterohelicidae du Crétacé supérieur pyrènèen. Bull. Soc. Geol. France, 5(no. 18 [1-3]):15-35.

Lalicker. C. G., 1948. A new genus of foraminifera from the Upper Cretaceous. J. Paleontol., 22(no. 5):624.

Loeblich. A. R., Jr., and Tappan, H., 1964. Foraminiferida. In Moore, R. C. (Ed.), Treatise on Invertebrate Palaeontology. C: Protisto (Vol. 1, 2): New York (Geol. Soc. Am. and Univ. Kans. Press).

McNulty, C. L., 1979. Smaller Cretaceous foraminifers of Leg 43, Deep Sea Drilling Project. In Tucholke, B. E., Vogt, P. R., et al., Init. Repts. DSDP, 43: Washington (U.S. Govt. Printing Office), 487-505.

Martin, S. E., 1972. Reexamination of the Upper Cretaceous planktonic foraminiferal genera Planoglobulina Cushman and Ventilabrella Cushman. J. Foraminiferal Res., 2(no. 2):73-92.

Montanaro Gallitelli, E., 1957. A revision of the foraminiferal family Heterohelicidae. Bull. U.S. Nat. Mus., 215:133-154.

Nakkady, S., 1950. A new foraminiferal fauna from the Esna Shales and Upper Cretaceous Chalk of Egypt. J. Paleontol., 24(no. 6): 675-692.

Nyong, E. E., 1984. Campanian to lower Maastrichtian paleobiogeography of the western North Atlantic region. Eclogae Geol. Helv., 77(no. 3):469-481.

Pessagno, E. A., 1967. Upper Cretaceous planktonic foraminifera from the western Gulf Coastal Plain. Paleontol. Am., 5(no. 37):245-445.

Plummer, H. J., 1926. Foraminifers of the Midway Formation in Texas. Texas Univ. Bull., 2644.

1931. Some Cretaceous foraminifera in Texas. Bull. Univ. Texas, Bur. Econ. Technol., 3101:109-203.

Postuma, J. A., 1962. Manual of Planktonic Foraminifera: Amsterdam (Elsevier).
Reiss, Z., 1957. The Bilaminellidae, nov, superfam., and remarks on Cretaceous Globorotaliids. Contrib. Cushman Found. Foraminiferal Res., 8(no. 4):127-145.

Robaszynski. F., Caron M., Gonzalez Donoso, J. M., and Wonders, A. (Eds.), 1984. Atlas of Late Cretaceous globotruncanids. Rev. Micropaleontol., 26., No. 3-4.

Rzehak, A., 1891. Der Foraminiferenfauna der alttertiären Ablagerungen von Brudendorf in Niederösterrreich, mit berücksichtigung des angeblichen Kreidenvorkommens von Leitersdorf. Ann. Naturh. Hofmus., 6:1-12.

Sigal J., 1952. Apercu stratigraphique sur la micropaléontolgie du Crétacé. Alger. 19th Int. Geol. Congr. Monogr. Reg., Ist Ser., 26:1-45.

Tilev, N., 1951. Etude des Rosalines Maestrichtienne (genre Globotruncana) du Sud-Est de la Turquie (sondage de Ramandag). Lausanne Univ. Lab. Geol. Min., Geophys. Mus. Geol. Bull., 103: $1-86$.

Todd, R., 1979. Maestrichtian (Late Cretaceous) foraminifera from a deep-sea core of southwestern Africa. Rev. Espan. Micropaleontol., 2(no.2):131-154.

van Hinte, J. E., 1963. Zur Stratigraphie und Mikropaläontologie der Oberkreide und des Eozäns des Krappfeldes (Kärnten). Jahrb. Geol. Bundes. Osterr., Sonderb., 8:1-147.

1967. Bolivinoides from the Campanian type section. Proc. K. Ned. Akad. Wet., Ser. B, 70:254-263.

1976. A Cretaceous time scale. Am. Assoc. Pet. Geol. Bull., 60(no. 4):269-287.

Vincent, E., and Berger, W. H., 1981. Planktonic foraminifera and their use in paleoceanography. In Emiliani C. (Ed.), The Oceanic Lithosphere, The Sea (Vol. 7): New York (John Wiley \& Sons), 1025-1119.

Voorwijk, G. H., 1937. Foraminifera from the upper Cretaceous of Habana, Cuba. Proc. K. Akad. Wet., Sect. Sci., 40:190-198.

White, M. P., 1928. Some index foraminifera of the Tampico Embayment area of Mexico. J. Paleontol., 2(no. 4):280-317.

Date of Initial Receipt: 5 June 1985

Date of Acceptance: 17 February 1986 


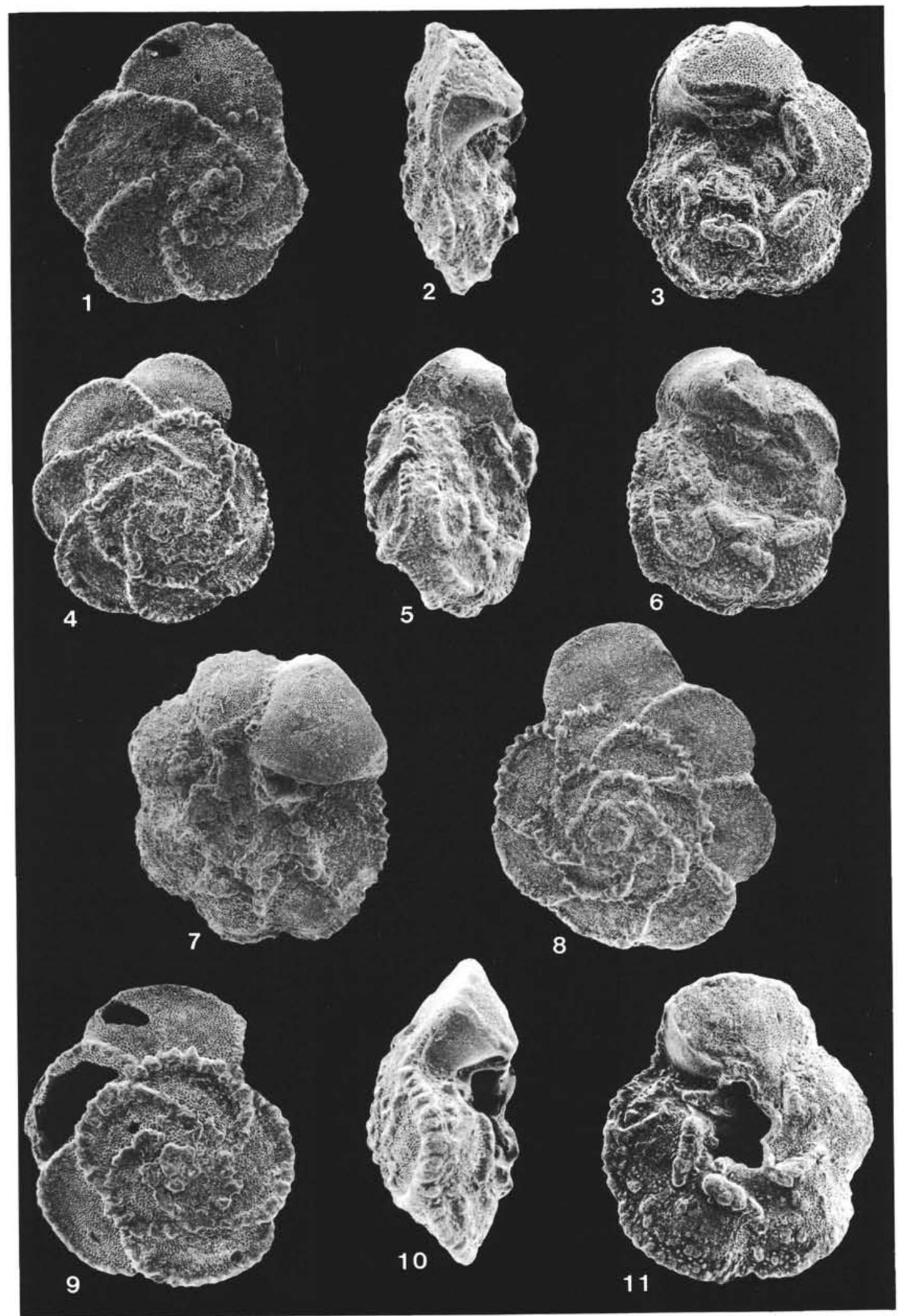

Plate 1. 1-3. Globotruncana aegyptiaca Nakkady, 65×, Sample 605-66-2, 59-62 cm, (1) spiral side; (2) side view, same specimen; (3) umbilical side, same specimen. 4-6. Globotruncana arca (Cushman), 52×, Sample 605-71-2, 60-62 cm, (4) spiral side; (5) side view, same specimen; (6) umbilical side, same specimen. 7, 8. Globotruncana falsostuarti Sigal, 52×, Sample 605-69-1, 60-62 cm, (7) umbilical side; (8) spiral side. 911. Globotruncana rosetta (Carsey), $65 \times$, Sample 605-66-2, 59-62 cm, (9) spiral side; (10) side view specimen; (11) umbilical view, same specimen. Note that it has only 5 chambers in the last whorl and a faint second keel on the earlier chambers. 

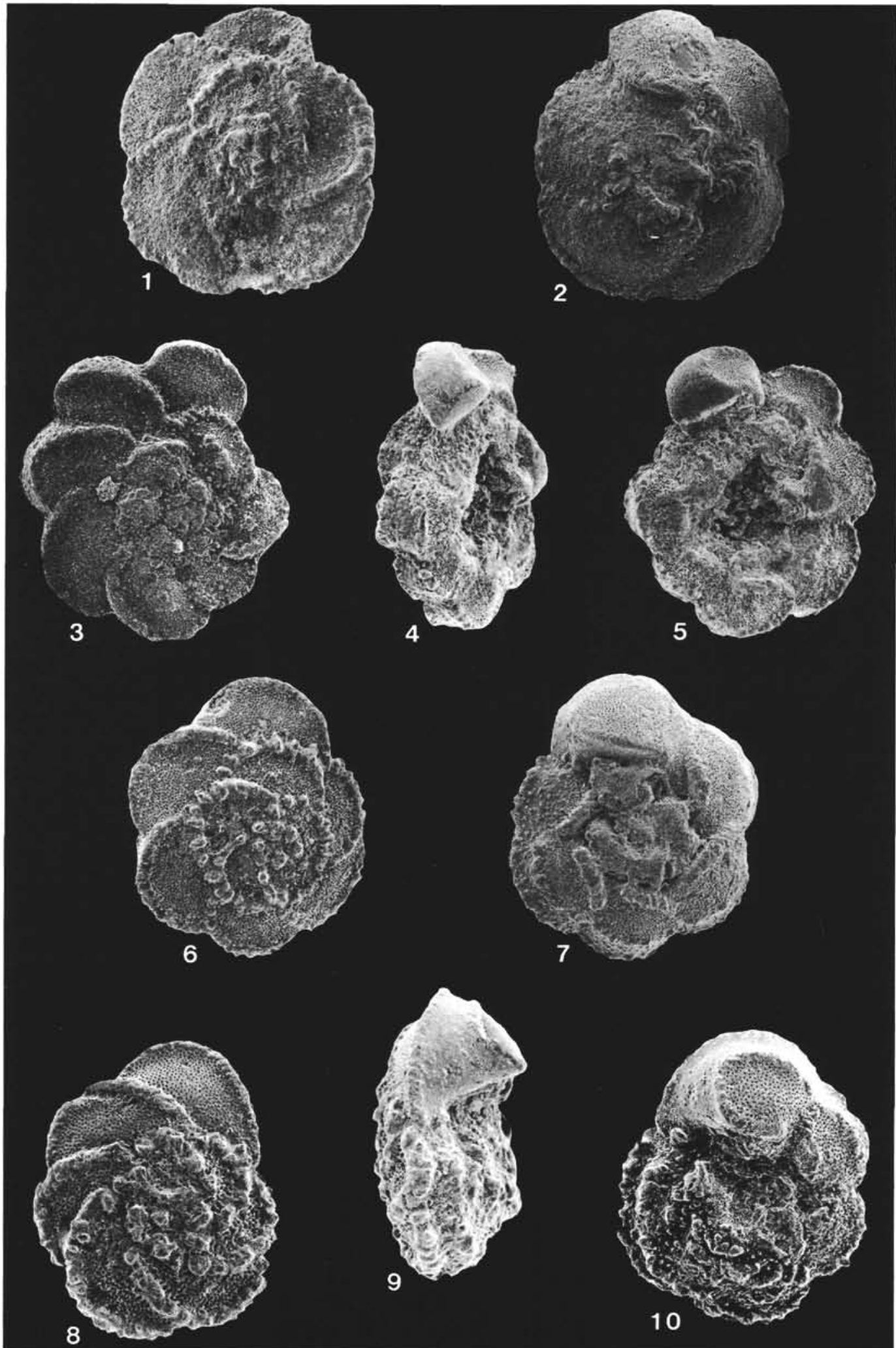

2

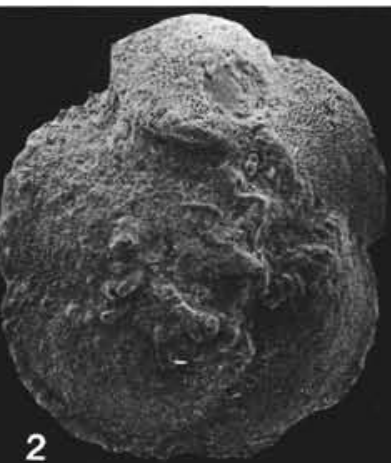




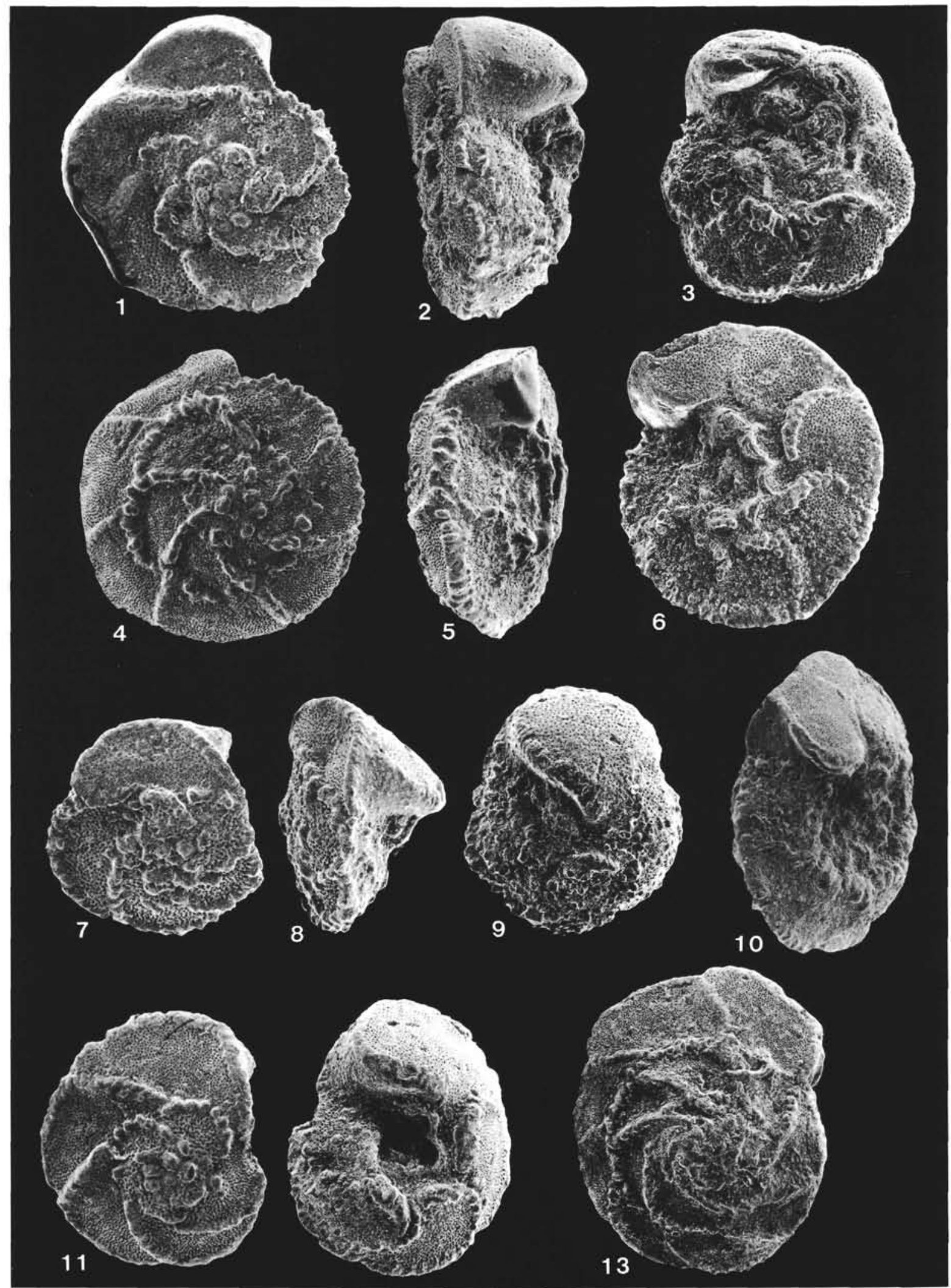

Plate 3. 1-3, 7-9. Globotruncana gansseri Bolli, 84.5×, (1-3) Sample 605-71-3, 60-62 cm (1, spiral side; 2 , side view, same specimen, showing faint row of pustules parallel to the keel; 3, umbilical side, same specimen); (7-9) Sample 605-70-1, 60-62 cm (7, spiral side; 8, side view, same specimen; 9, umbilical side, same specimen). 4-6. Globotruncana conica (White) 65×, Sample 605-69-3, 60-62 cm, (4) spiral side; (5) side view, same specimen; (6) umbilical side, same specimen. 11, 12. Globotruncana stuartiformis (Dalbiez), 65 $\times$, Sample 605-71-4, 60-62 cm, (11) spiral side; (12) umbilical side, same specimen. 10, 13. Globotruncana stuarti (de Lapparent), 45.5×, Sample 605-68,CC, (10) side view; (13) spiral side, same specimen. 


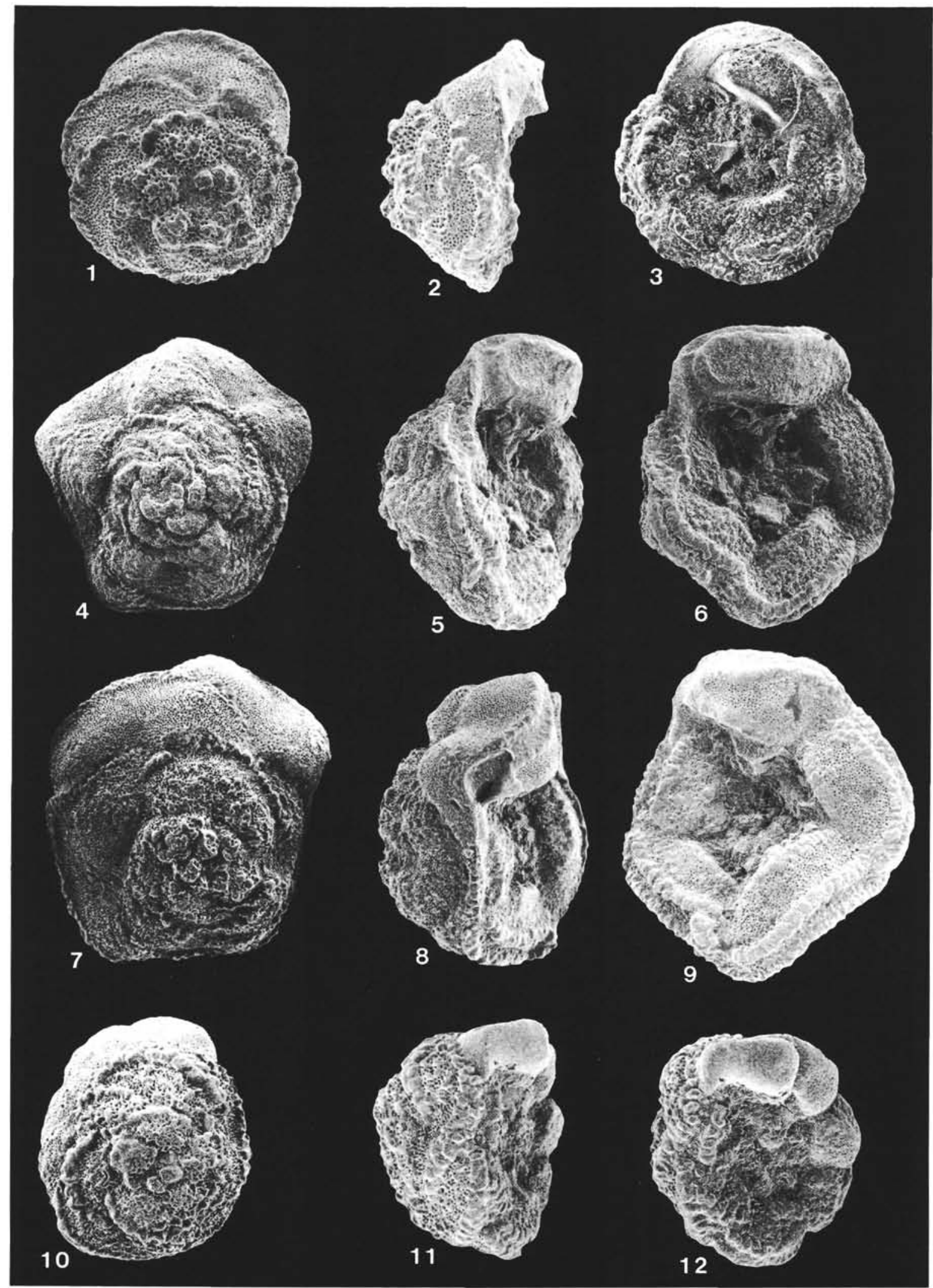

Plate 4. 1-3. Globotruncana fornicata Plummer, $91 \times$, Sample $605-70-3,60-62 \mathrm{~cm}$, (1) spiral side; (2) side view, same specimen; (3) umbilical side, same specimen. 4-9. Globotruncana contusa (Cushman), (4-6) 45.5 , Sample 605-69-3, 60-62 cm (4, spiral side; 5, side view, same specimen; 6, umbilical side, same specimen); (7-9) 71.5 , Sample 605-70-3, 60-62 cm, (7, spiral side; 8, side view, same specimen; 9 , umbilical side, same specimen). 10-12. Globotruncana walfischensis (Todd), 65×, Sample 605-71,CC, (10) spiral side; note rounded outline; (11) side view, same specimen; note rounded cup shape; (12) umbilical side. 


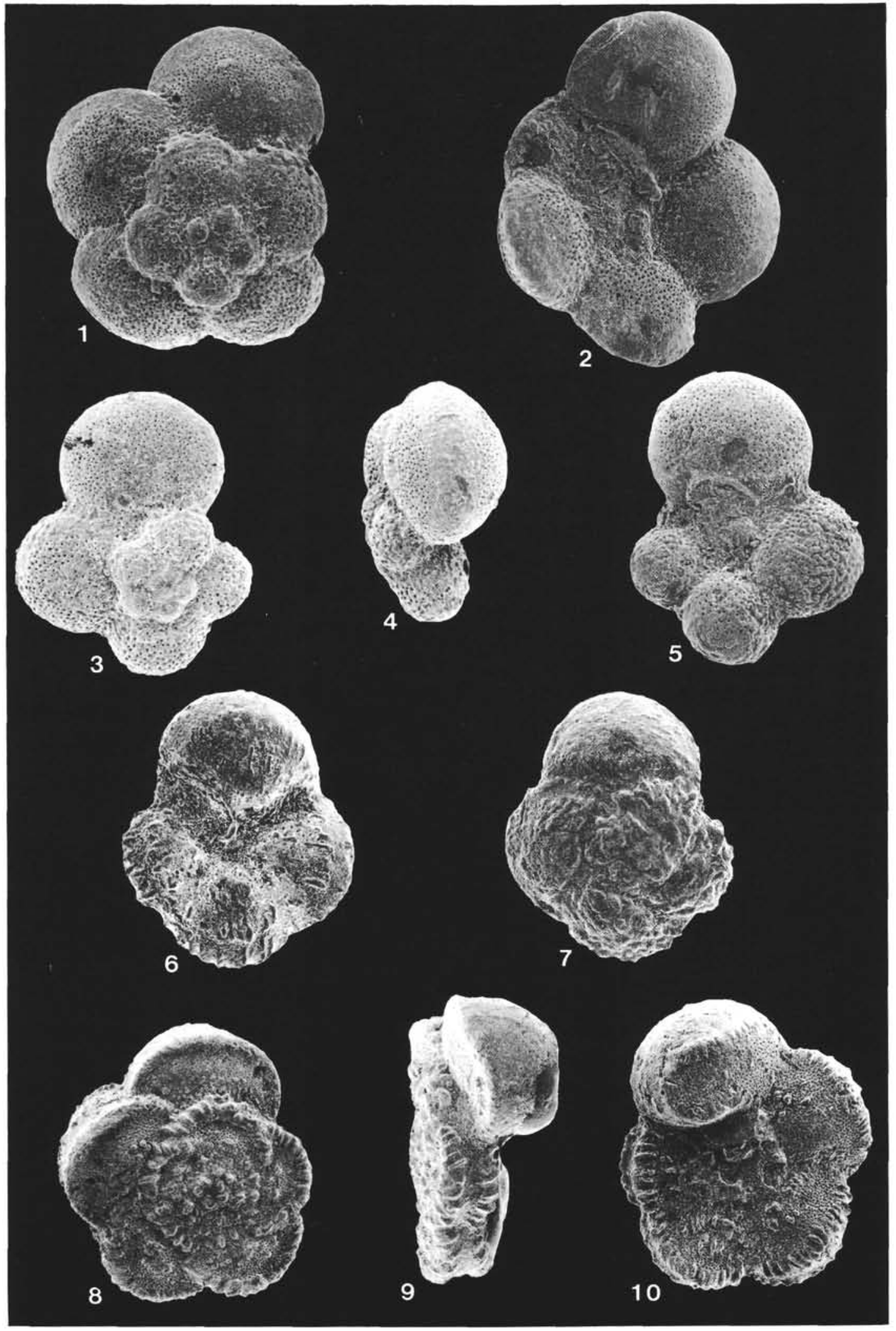

Plate 5. 1, 2. Globotruncanella havanensis (Voorwijk), 104×, Sample 605-70,CC, (1) spiral side; (2) umbilical side, same specimen, showing flattened chambers which are tilted toward the umbilicus. 3-5. Globotruncanella petaloidea (Gandolfi), $104 \times$, Sample $605-68-4,60-62 \mathrm{~cm},(3) \mathrm{spi}-$ ral side; (4) side view, same specimen, showing less pinched chambers, not tilted toward, the umbilicus; (5) umbilical side. 6, 7. Abathomphalus intermedius (Bolli), $97.5 \times$, Sample 605-66-2, 28-30 cm, (6) umbilical side; (7) spiral side, same specimen. 8-10. Abathomphalus mayaroensis (Bolli), 52×, Sample 605-66-2, 60-62 cm, (8) spiral side; (9) side view, same specimen; (10) umbilical side, same specimen; note narrow umbilicus. 


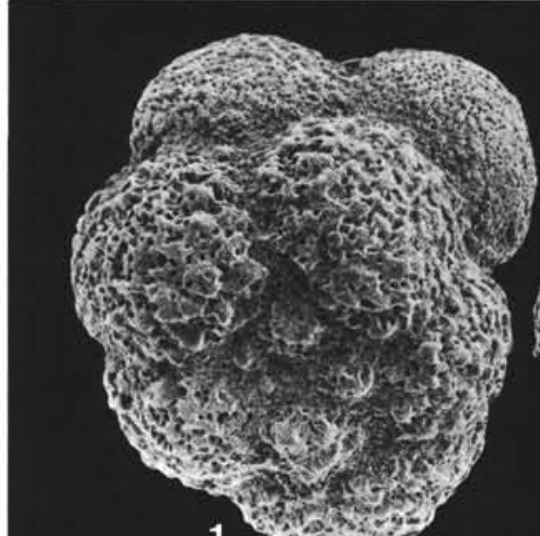

1
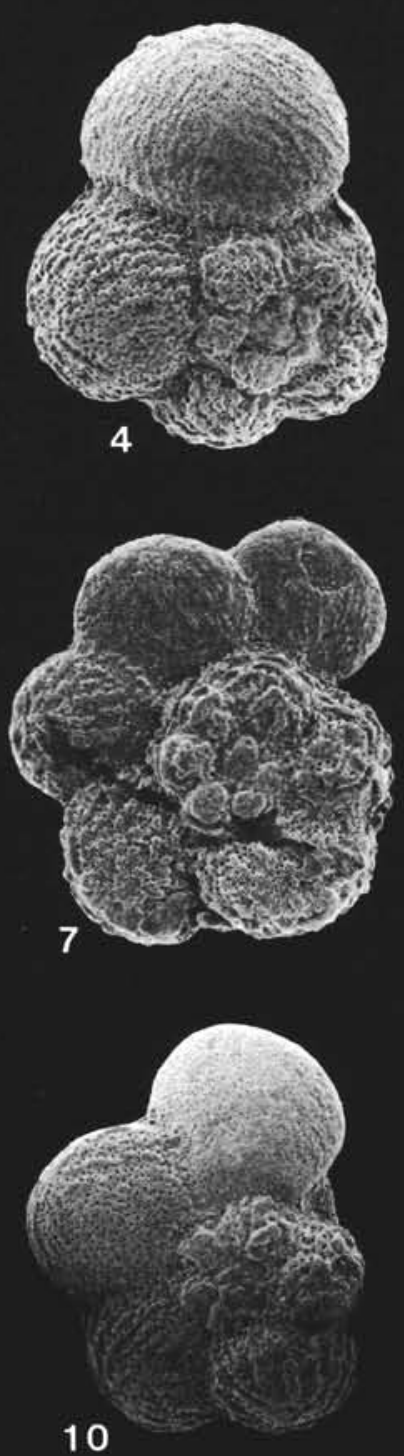

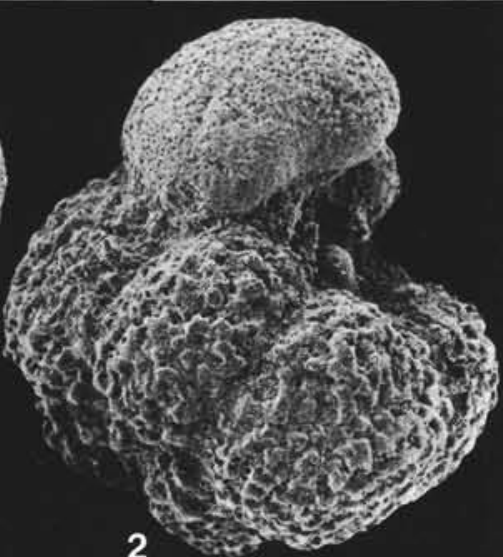

2

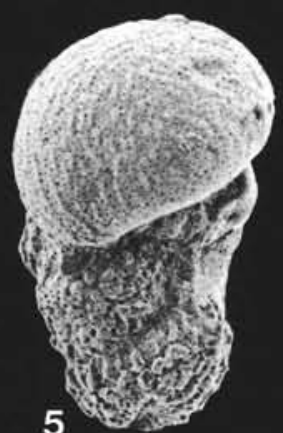

5
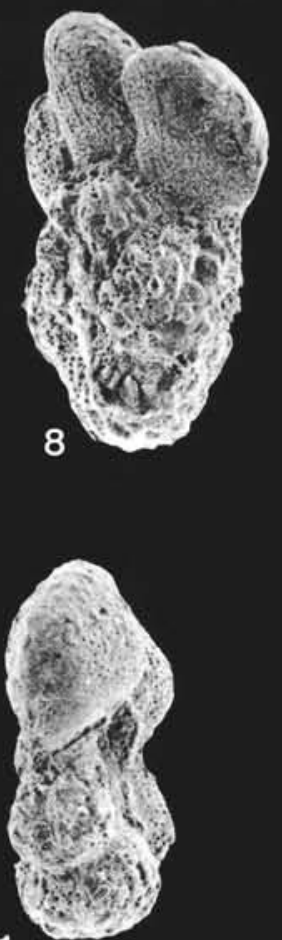

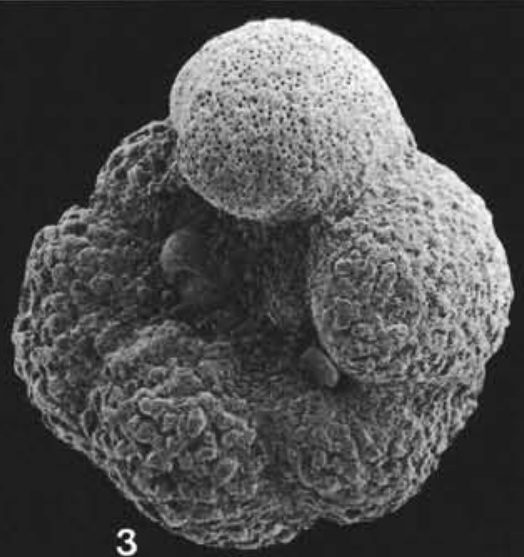

3
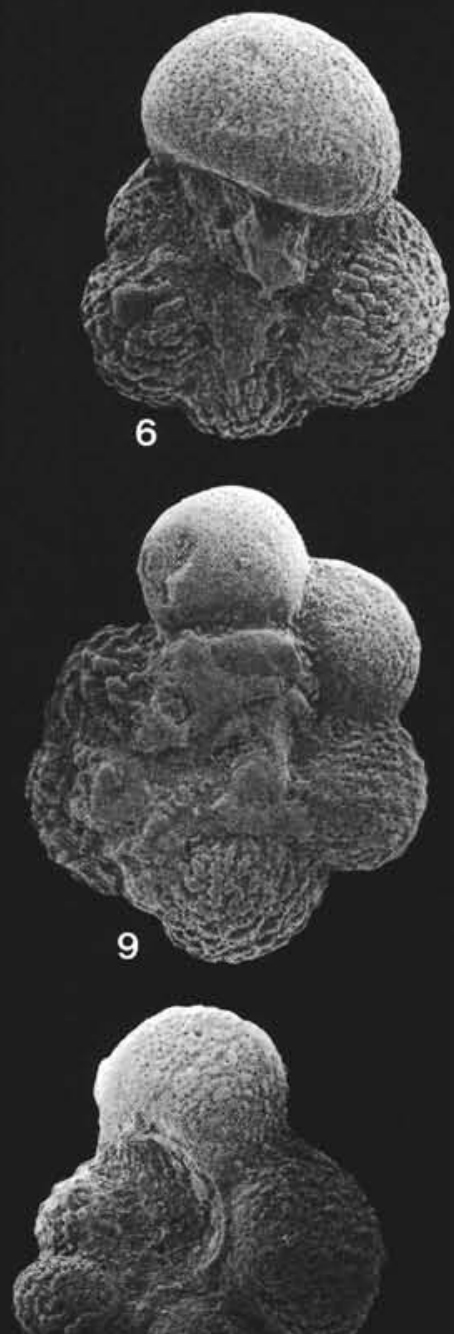

12

Plate 6. 1-3. Rugoglobigerina rotundata Brönnimann, $78 \times$, Sample $605-66, C C$, (1) spiral side, showing lack of costellae in a meridional pattern; (2) side view, showing displacement of final chambers toward the umbilicus; (3) umbilical side, same specimen. 4-6. Rugoglobigerina rugosa (Plummer), 84.5 $\times$, Sample 605-67-3, 44-46 cm, (4) spiral side; (5) side view, same specimen; (6) umbilical side, same specimen. 7-12. Rugoglobigerina scotti (Brönnimann), 78 $\times$, Sample 605-66,CC, (7) spiral side; (8) side view, same specimen, showing flattened final chambers; (9) umbilical side. (10) spiral side of smaller specimen; (11) side view, same specimen; (12) umbilical side, same specimen. 


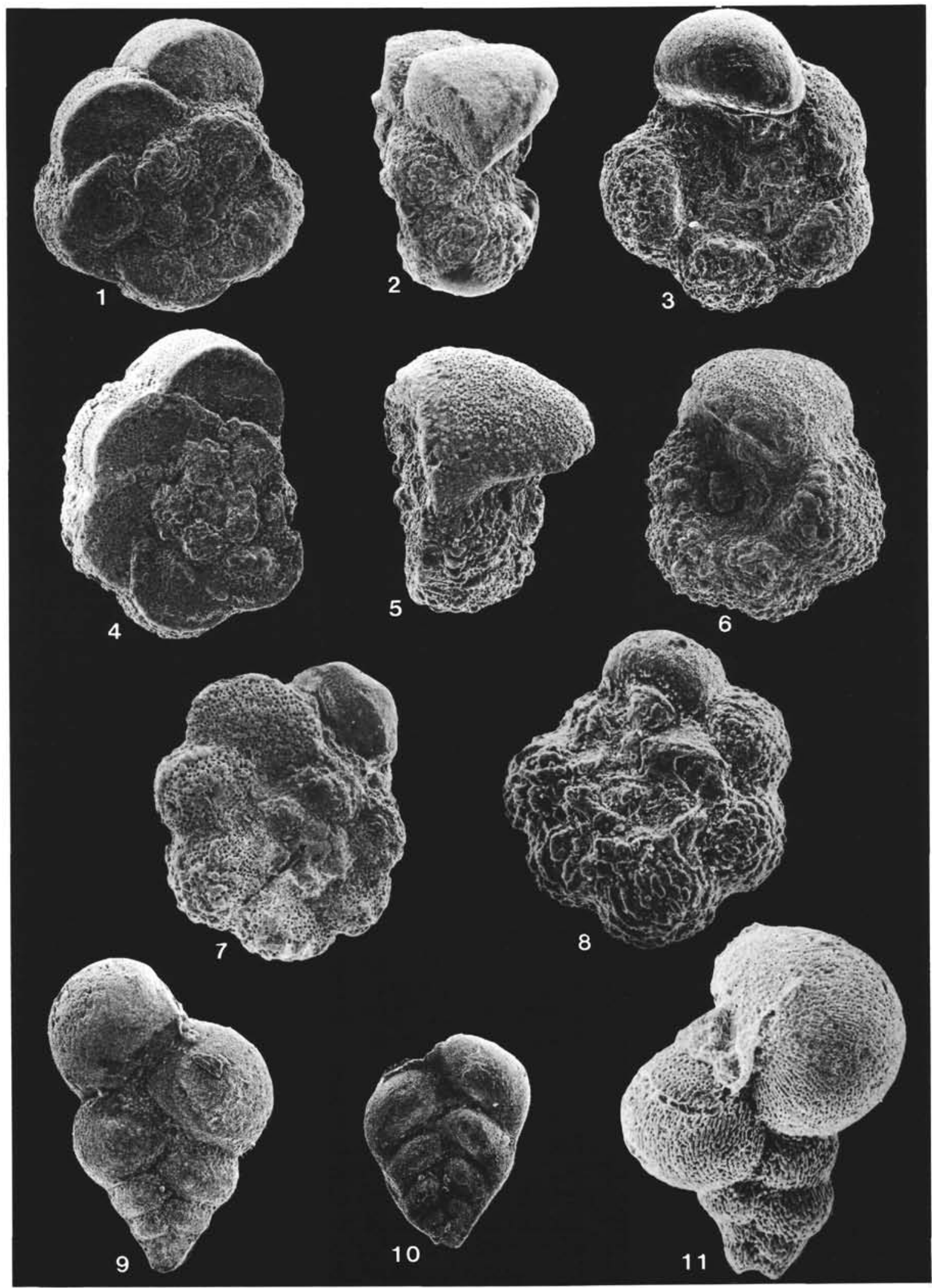

Plate 7. 1-6. Globotruncana gansseri Bolli, $84.5 \times$, (1-3) Sample $605-67-4,46-48 \mathrm{~cm}$ (1, spiral side showing slightly imbricate chamber arrangement; 2, side view, same specimen; 3, umbilical side showing lack of adumbilical ridge); (4-6) Sample 605-68-1, 60-62 cm (4, spiral side; 5, side view showing row of pustules along the keel; 6 , umbilical side, same specimen). 7, 8. Rugoglobigerina hexacamerata Brönnimann, $97.5 \times$, Sample 605-68-3, 60-62 cm, (7) spiral side; (8) umbilical side, same specimen. 9. Heterohelix glabrans Cushman, 97.5 $\times$, Sample 605-69-2, 60$62 \mathrm{~cm}$, side view showing chambers increasing rapidly in size. 10. Heterohelix pulchra (Brotzen), 123.5 $\times$, Sample 605-71,CC, side view showing reniform chambers. 11. Heterohelix globulosa (Ehrenberg), 113.8 $\times$, Sample 605-69-5, 60-62 cm, side view; this specimen resembles Heterohelix striata (Ehrenberg) in possessing very fine striae. 


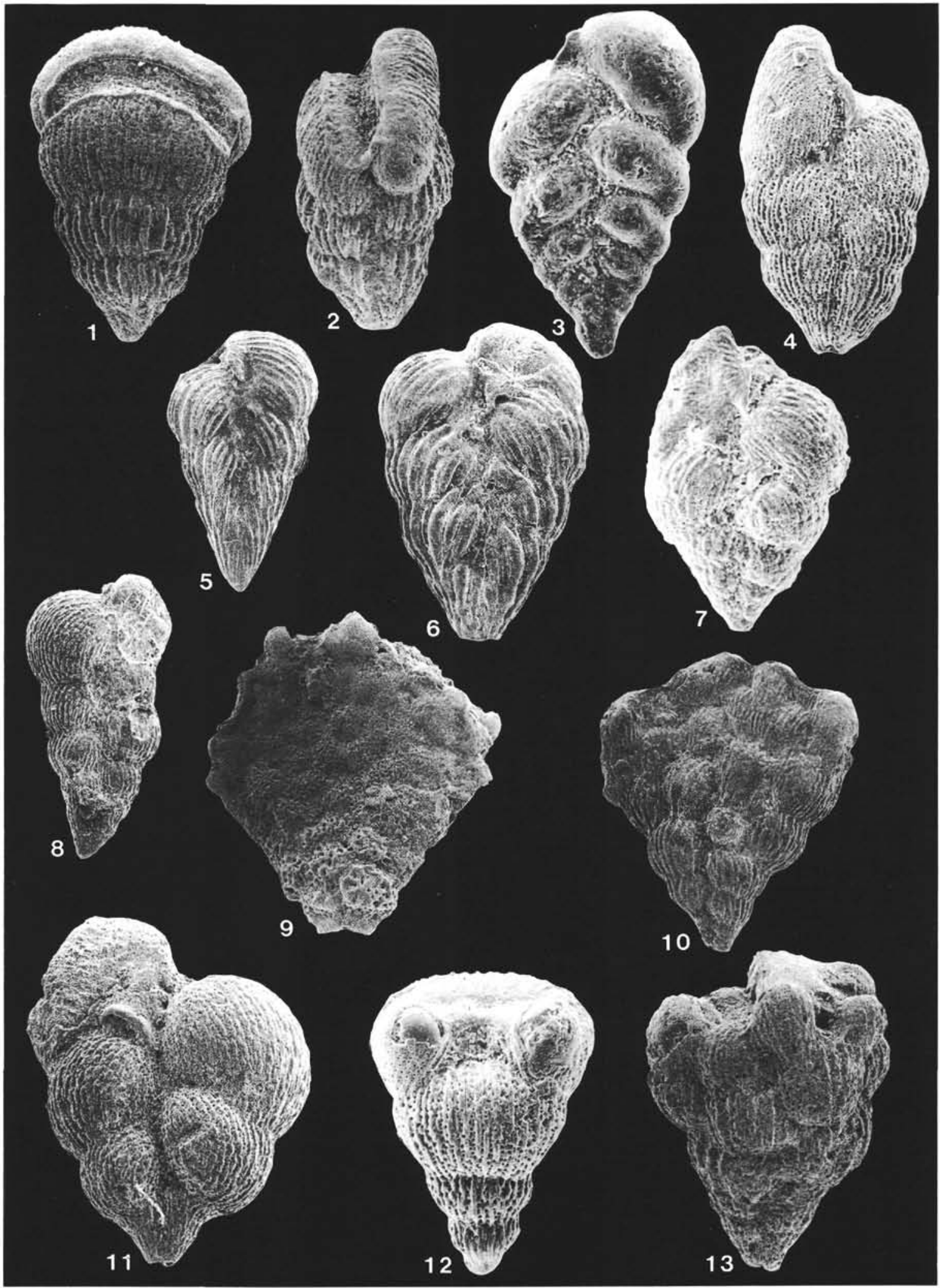

Plate 8. 1, 2. Pseudotextularia elegans (Rzehak), 78 $\times$, Sample 605-69-4, 60-62 cm, (1) side view, typical flared outline; (2) side view; chambers do not increase in size after the first few. 3. Heterohelix sp. 1., 97.5 $\times$, Sample 605-66,CC, side view. 4. Heterohelix sp. 2, 97.5 $\times$, Sample 605$66, \mathrm{CC}$, side view; note elongation in the direction of growth. 5. Pseudoguembelina costulata (Cushman), 110.5 $\times$, Sample 605-69-2, 60-62 cm, side view. 6. Pseudoguembelina excolata (Cushman), 97.5 $\times$, Sample 605-68-4, 60-62 cm, side view. 7. Pseudoguembelina sp. 1, 97.5 $\times$, Sample 605-66-4, 124-126 cm, side view. 8. Heterohelix sp. 3, 97.5 , Sample 605-69-2, 60-62 cm, side view showing fine striae. 9. Ventilabrella multicamerata de Klasz, $65 \times$, Sample 605-69-3, 60-62 cm, side view. 10. Planoglobulina acervulinoides (Egger), 52×, Sample 605-71-3, 60-62 cm, side view. 11. Pseudoguembelina palpebra Brönnimann and Brown, $97.5 \times$, Sample 605-66,CC, side view showing accessory aperature. 12. Racemiguembelina intermedia (de Klasz), $97.5 \times$, Sample $605-71-4,60-62 \mathrm{~cm}$, side view. 13. Racemiguembelina fructicosa (Egger), $97.5 \times$, Sample 605-69-4, 60-62 cm, side view. 


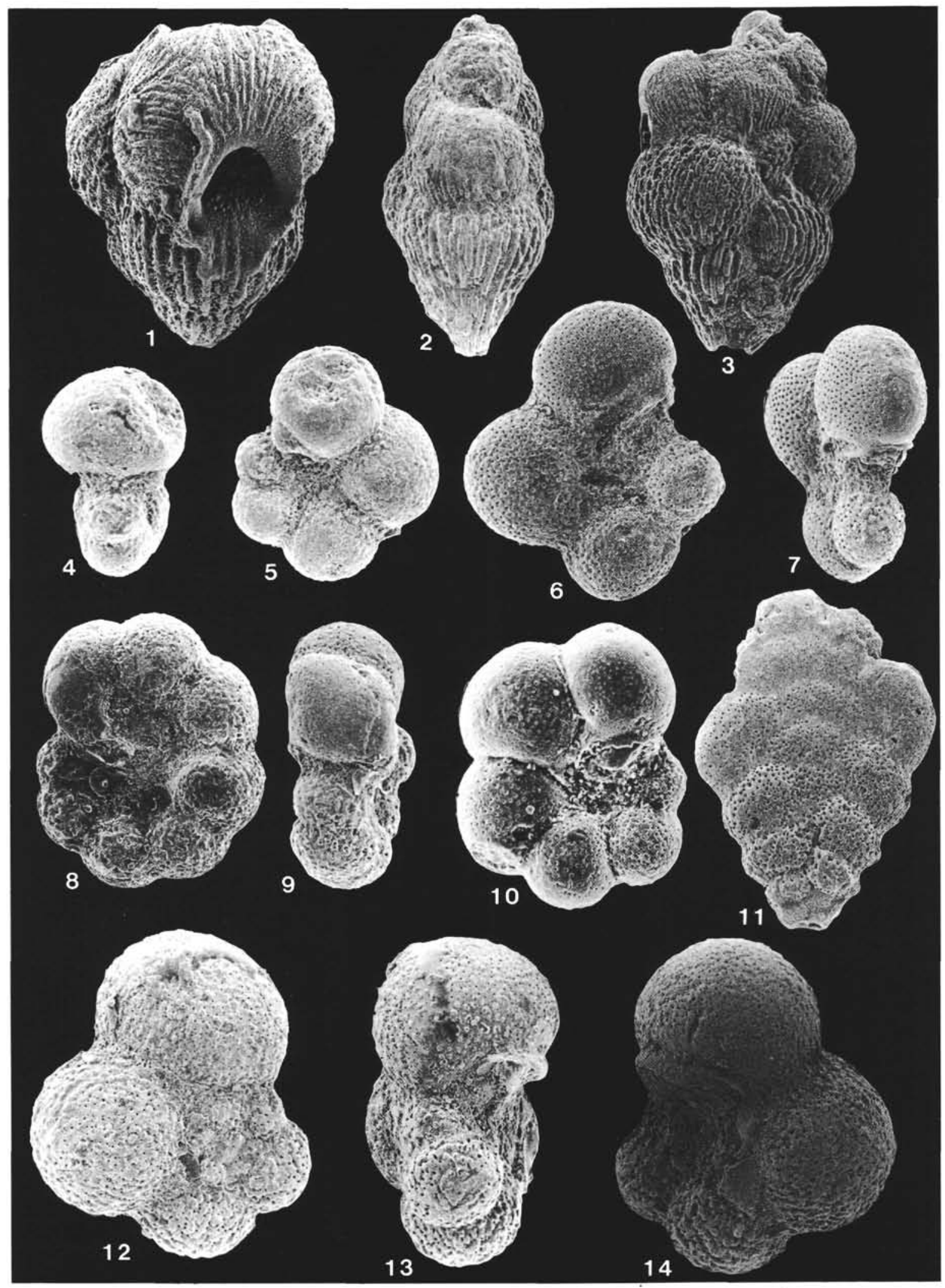

Plate 9. 1-3. Planoglobulina brazoensis Martin (1), $117 \times$, Sample $605-66-2,59-62 \mathrm{~cm}$, side view showing accessory aperture and rapid increase in chamber size of the early chambers; (2-3) $78 \times$, Sample $605-66-2,59-62 \mathrm{~cm},(2$, side view; 3 , serial view, same specimen). 4, 5. Globigerinelloides multispinata (Lalicker), $117 \times$, Sample 605-67-2, 32-34 cm, (4) side view; (5) umbilical view, same specimen. 6, 7. Globigerinelloides subcarinatus (Brönnimann), $117 \times$, Sample 605-67-3, 44-46 cm, (6) umbilical view; (7) side view showing lateral compression of chambers. 8, 9. Globigerinelloides sp. $2,117 \times$, Sample $605-67-3,44-46 \mathrm{~cm},(8)$ umbilical view; (9) side view. 10. Globigerinelloides sp. 1, 117 $\times$, Sample $605-67-3$, $44-46 \mathrm{~cm}$, umbilical view. 11. Gublerina cuvillieri Kikoine, $84.5 \times$, Sample 605-66-3, 124-126 cm, side view. 12-14. Archaeoglobigerina sp. $123.5 \times$, Sample 605-67-3, 44-46 cm, (12) spiral side, (13) side view, (14) umbilical side. 